\title{
Increased Expression of Apolipoprotein E in Transgenic Rabbits Results in Reduced Levels of Very Low Density Lipoproteins and an Accumulation of Low Density Lipoproteins in Plasma
}

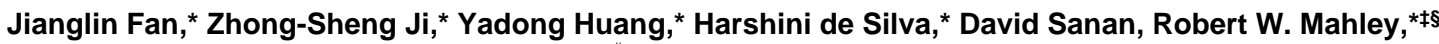 \\ Thomas L. Innerarity, ${ }^{* \neq}$ and John M. Taylor*\| \\ Gladstone Institute of Cardiovascular Disease, San Francisco, California 94141; *Cardiovascular Research Institute, ${ }^{\ddagger}$ Department of \\ Pathology, ${ }^{\S}$ Department of Medicine, and ${ }^{\|}$Department of Physiology, University of California, San Francisco, California 94143
}

\begin{abstract}
Transgenic rabbits expressing human apo E3 were generated to investigate mechanisms by which apo $\mathrm{E}$ modulates plasma lipoprotein metabolism. Compared with nontransgenic littermates expressing $\sim 3 \mathrm{mg} / \mathrm{dl}$ of endogenous rabbit apo E, male transgenic rabbits expressing $\sim 13 \mathrm{mg} / \mathrm{dl}$ of human apo $\mathrm{E}$ had a $35 \%$ decrease in total plasma triglycerides that was due to a reduction in VLDL levels and an absence of large VLDL. With its greater content of apo E, transgenic VLDL had an increased binding affinity for the LDL receptor in vitro, and injected chylomicrons were cleared more rapidly by the liver in transgenic rabbits. In contrast to triglyceride changes, transgenic rabbits had a $70 \%$ increase in plasma cholesterol levels due to an accumulation of LDL and apo E-rich HDL. Transgenic and control LDL had the same binding affinity for the LDL receptor. Both transgenic and control rabbits had similar LDL receptor levels, but intravenously injected human LDL were cleared more slowly in transgenic rabbits than in controls. Changes in lipoprotein lipolysis did not contribute to the accumulation of LDL or the reduction in VLDL levels. These observations suggest that the increased content of apo E3 on triglyceride-rich remnant lipoproteins in transgenic rabbits confers a greater affinity for cell surface receptors, thereby increasing remnant clearance from plasma. The apo E-rich large remnants appear to compete more effectively than LDL for receptormediated binding and clearance, resulting in delayed clearance and the accumulation of LDL in plasma. (J. Clin. Invest. 1998. 101:2151-2164.) Key words: remnant lipoproteins • lipoprotein receptors • transgenic rabbits • apo $\mathrm{E}$
\end{abstract}

\section{Introduction}

Apo $\mathrm{E}$ is a constituent of chylomicrons, VLDL, intermediate density lipoproteins (IDL) ${ }^{1}$ and subclasses of HDL that medi-

\footnotetext{
Address correspondence to John M. Taylor, Gladstone Institute of Cardiovascular Disease, P.O. Box 419100, San Francisco, CA 941419100. Phone: 415-826-7500. FAX: 415-285-5632. E-mail: john_taylor@ quickmail.ucsf.edu

Received for publication 25 August 1997 and accepted in revised form 12 March 1998.
}

1. Abbreviations used in this paper: HL, hepatic lipase; HSPG, heparan sulfate proteoglycans; IDL, intermediate density lipoproteins; LPL, lipoprotein lipase.

The Journal of Clinical Investigation

Volume 101, Number 10, May 1998, 2151-2164

http://www.jci.org ate remnant clearance and plasma cholesterol homeostasis (reviewed in reference 1). Through its association with HDL (1), apo $\mathrm{E}$ also participates in reverse cholesterol transport. Human apo $E$ is a single-chain polypeptide of 299 amino acids $\left(34,200 M_{\mathrm{r}}\right)$, encoded by a gene of 3,597 nucleotides with four exons and three introns that is located on the long arm of chromosome 19 (2-4). The liver is the major source of apo E in plasma (5), although substantial amounts of apo E are produced by many other tissues $(6,7)$. Several variants of apo E have been detected in the human population: the E3 isoform $\left(\mathrm{Cys}_{112}, \mathrm{Arg}_{158}\right)$ is most common (1).

The actions of apo E in lipid metabolism are primarily a consequence of its ability to bind to the LDL receptor, the LDL receptor-related protein, and heparan sulfate proteoglycans (HSPG) (1, 8-11). Residues 136-150 in human apo E constitute the domain responsible for these binding activities, but subtle conformational changes in internal domain-domain interactions directed by residues $\mathrm{Arg}_{61}$ and $\mathrm{Glu}_{255}$ affect apo E functions (12). The naturally occurring E2 isoform of apo E $\left(\mathrm{Cys}_{112}, \mathrm{Cys}_{158}\right)$ is defective in binding to receptors and is associated with familial type III hypercholesterolemia, a genetic disorder characterized by elevated plasma cholesterol and triglyceride levels and accelerated coronary artery disease (9). The E4 isoform of apo $\mathrm{E}\left(\mathrm{Arg}_{112}, \mathrm{Arg}_{158}\right)$ is a risk factor for atherosclerosis (13) and has been implicated in the pathogenesis of Alzheimer's disease $(14,15)$. To investigate the mechanisms of apo E's action in lipoprotein metabolism, we generated transgenic rabbits that express elevated levels of human apo E3.

Several characteristics of the rabbit recommend it for these studies. Rabbits have 30-50\% less plasma apo E than humans (16) and $50-70 \%$ less than mice (17); thus, the rabbit is likely to be relatively sensitive to the level of circulating apo E. Transient infusion of apo $\mathrm{E}$ into the circulation increases the clearance of $\beta$-VLDL in cholesterol-fed normal rabbits and in Watanabe heritable hyperlipidemic rabbits, a model of familial hypercholesterolemia $(18,19)$. The low level of apo $\mathrm{E}$ has been thought to be one reason why normal rabbits are exceptionally sensitive to dietary cholesterol, developing severe hypercholesterolemia that is associated with the rapid development of atherosclerosis (20).

The rabbit is naturally deficient in hepatic lipase (HL) (21), an enzyme that is required to catabolize IDL and large HDL (reviewed in reference 22). The HL content in the rabbit is $\sim 10 \%$ of that in rodents. In rabbits, HL is bound to extracellular surfaces and is found mainly on sinusoidal endothelial cells and on the microvillar surface of hepatocytes in the space of Disse in the liver (23), whereas in mice most of the HL circulates in plasma (24). HL accelerates the apo E-mediated uptake of chylomicron remnants by cultured hepatoma cells (25), and the enzymatic activity of HL is enhanced by apo 
$\mathrm{E}$ in vitro (26). In addition, HL increases the binding and uptake of HDL by cultured hepatoma cells, an effect that is enhanced by low levels of apo E, but reduced by high concentrations of apo E (27).

Additional characteristics of the rabbit contribute significantly to plasma lipoprotein metabolism and would be expected to affect transgene expression. The rabbit has abundant levels of cholesteryl ester transfer protein (28), which should facilitate the metabolic interaction between the VLDL and HDL pathways. Rabbit liver does not edit apo B100 mRNA, whereas mouse liver edits most of the apo B100 mRNA to the B48 form (29). Bile production in rabbits is somewhat limited by a relative deficiency in the mRNA levels for 7- $\alpha$ hydroxylase, the rate-limiting enzyme in bile acid synthesis (30).

In this report, we describe the effects of the constitutively increased expression of human apo $\mathrm{E}$ on plasma lipoproteins in the transgenic rabbit. We find that essentially all classes of lipoproteins are affected by the presence of excess apo E, a likely reflection of its diverse functions. The effects of human apo E expression in transgenic rabbits are strikingly different from those in transgenic mice, providing a compelling argument for the use of transgenic rabbit models to investigate lipoprotein metabolism.

\section{Methods}

Production of transgenic rabbits. The construct used to generate transgenic rabbits (HEG.LE1) was described previously: it contains the complete human apo E gene together with $5 \mathrm{~kb}$ of its $5^{\prime}$ flanking sequence and $1.7 \mathrm{~kb}$ of its $3^{\prime}$ flanking sequence, ligated to a $3.8-\mathrm{kb}$ downstream fragment containing the hepatic control region for this gene, which directs high levels of expression of apo $\mathrm{E}$ in the liver with little expression in any other tissue (31). Transgenic rabbits were generated using specific pathogen-free New Zealand White rabbits (Charles River, Montreal, Quebec, Canada) and methods as described previously $(32,33)$. Three founders were identified by Southern blot analysis (34), and gene copy numbers were estimated by densitometric scanning of the Southern blots. These founders were mated with nontransgenic rabbits to produce F1 progeny. All animals used for the current study were 4-6 mo old and were maintained on Lab Rabbit Chow HF (Purina Mills, Richmond, IN) containing 1.5\% vegetable fat, $14 \%$ protein, and $25 \%$ crude fiber. The animals had free access to water and were housed in a barrier facility with a 12-h light/dark cycle at $23^{\circ} \mathrm{C}$ and $55 \%$ humidity. All experimental procedures with rabbits were conducted in accordance with National Institutes of Health Guidelines and with the approval of the Committee on Animal Research of the University of California, San Francisco.

To confirm the identity of the human apo E that was expressed by the above construct, total liver RNA was prepared from a transgenic rabbit, and the human apo E cDNA was cloned by PCR with oligonucleotides corresponding to nontranslated regions. The nucleotide sequence of the cloned cDNA was determined (data not shown). The portion of the cDNA corresponding to mature human plasma apo $\mathrm{E}$ had a predicted amino acid sequence that was identical to that of the E3 isoform (reviewed in reference 35). We also confirmed the sequence of the endogenous rabbit apo $\mathrm{E}$ in our transgenic animals: rabbit apo $\mathrm{E}$ contains cysteine and arginine at positions corresponding to those of the E3 isoform of human apo E (36).

Human apo E expression. Western blots of rabbit plasma (32) were performed on samples $(1 \mu \mathrm{l})$ that had been resolved by PAGE with 4-20\% gels (EP Mini System, Schleicher \& Schuell, Inc., Keene, $\mathrm{NH}$ ) containing $0.1 \%$ SDS. Apo E was detected with a human-specific apo $\mathrm{E}$ antibody (prepared in goats) that did not cross-react with rabbit apo $\mathrm{E}$. The level of human apo $\mathrm{E}$ in the plasma of transgenic rabbits was estimated by ELISA using the same polyclonal antibody and by Western blot analysis of whole plasma using purified human apo E standards for comparison. Antibodies and apo E standards were generously provided by K.H. Weisgraber (J. David Gladstone Institutes, San Francisco, CA).

Lipoprotein analysis. Rabbits were fasted overnight (14-16 h). Blood was collected between 8:00 and 9:00 a.m. from the intermedial auricular artery and adjusted to a final concentration of $1.5 \mathrm{mg} / \mathrm{ml}$ EDTA and $50 \mathrm{U} / \mathrm{ml}$ Trasylol pancreatic protease inhibitor (Miles Laboratory, New Haven, CT). Plasma was separated by centrifugation at $3,000 \mathrm{rpm}$ for $20 \mathrm{~min}$ at $4^{\circ} \mathrm{C}$, and lipoproteins were isolated by small-volume sequential ultracentrifugation with a Beckman TLA100.2 rotor as described (37). Isolated individual density fractions and whole plasma were resolved by electrophoresis in $1 \%$ agarose gels (37). Then, the gels were dried and stained with Fat Red 7B to identify lipoproteins containing neutral lipid, or the proteins in the gels were transferred to a nitrocellulose membrane and immunoblotted with specific antibodies against individual rabbit apolipoproteins (provided by K.H. Weisgraber). Immunocomplexed proteins were identified by reaction with a horseradish peroxidase-conjugated secondary antibody followed by chemiluminescent detection (ECL kit; Amersham, Arlington Heights, IL) as described $(32,37)$. Total cholesterol and triglyceride concentrations in whole plasma and in each density fraction were determined by enzymatic assays with an Abbott Spectrum Analyzer (Abbott, Abbott Park, IL) according to the manufacturer's directions. HDL cholesterol in whole plasma was measured using the StatSpin Micro HDL-C assay kit (StatSpin Technologies, Norwood, MA). The diameters of apo B-containing lipoproteins $(d<1.006$, and $d=1.006-1.02,1.02-1.04$, and $1.04-1.06 \mathrm{~g} / \mathrm{ml})$ were determined by negative-staining electron microscopy as described (32).

Receptor-binding assay. About $150 \mathrm{ml}$ of blood was collected and pooled from four female transgenic or nontransgenic rabbits and adjusted to a final concentration of $1.5 \mathrm{mg} / \mathrm{ml}$ EDTA and $50 \mathrm{U} / \mathrm{ml}$ Trasylol. Plasma lipoprotein density fractions were isolated by large-volume sequential ultracentrifugation with a Beckman 60 Ti rotor at $4^{\circ} \mathrm{C}$ as follows: $d<1.006 \mathrm{~g} / \mathrm{ml}$ (VLDL), 50,000 rpm for $16 \mathrm{~h}$, and then recentrifuged at $50,000 \mathrm{rpm}$ for $16 \mathrm{~h}$ at $d=1.02 \mathrm{~g} / \mathrm{ml} ; d=1.006-1.02$ $\mathrm{g} / \mathrm{ml}$ (IDL), 50,000 rpm for $18 \mathrm{~h}$, and then recentrifuged at 50,000 rpm for $18 \mathrm{~h}$ at $d=1.04 \mathrm{~g} / \mathrm{ml} ; d=1.02-1.04 \mathrm{~g} / \mathrm{ml}$ (large LDL) and $d=$ $1.04-1.06 \mathrm{~g} / \mathrm{ml}$ (small LDL), 59,000 rpm for $18 \mathrm{~h}$. Lipoproteins were dialyzed against $0.15 \mathrm{M} \mathrm{NaCl}$ and $0.01 \%$ EDTA overnight. Competition assays for lipoprotein binding to the LDL receptors of cultured human fibroblasts with human ${ }^{125} \mathrm{I}$-labeled LDL were performed at $4^{\circ} \mathrm{C}$ as described $(38,39)$. In this assay, the relative binding affinities of the rabbit lipoproteins are measured by their abilities to compete with human ${ }^{125} \mathrm{I}$-labeled LDL for binding to the LDL receptor.

To measure $\mathrm{HDL}_{1}$ receptor-binding affinity, the $d=1.02-1.04 \mathrm{~g} / \mathrm{ml}$ and $d=1.04-1.10 \mathrm{~g} / \mathrm{ml}$ lipoproteins were isolated from intermediateexpresser animals; then apo E-rich $\mathrm{HDL}_{1}$ and large $\mathrm{LDL}$ were purified further by Pevikon electrophoresis (40). Homogeneous preparations of $\mathrm{HDL}_{1}$ (separated from apo A-I-rich $\mathrm{HDL}_{2}$ ) and LDL (separated from $\mathrm{HDL}_{1}$ ) were eluted from Pevikon blocks. The ability of these purified fractions to compete with human LDL for binding to LDL receptors was measured in the above fibroblast assay.

Chylomicron clearance. Chylomicrons $(d<1.006 \mathrm{~g} / \mathrm{ml})$ were collected from the thoracic lymph duct of a dog that had been fed $\left[{ }^{14} \mathrm{C}\right]$ cholesterol and $\left[{ }^{3} \mathrm{H}\right]$ retinol in a fat-supplemented diet, isolated by ultracentrifugation, and characterized as described (41). For clearance measurements, transgenic rabbits and nontransgenic littermates were fasted overnight, and then labeled chylomicrons were infused quickly into an ear vein. Blood samples were collected at selected time points, tissues were collected after $20 \mathrm{~min}$, and radioactivity was measured as described (41).

Antibody clearance. Monoclonal antibody 9D9 is cleared rapidly from plasma as a result of specific binding to the rabbit cell surface LDL receptor, indirectly indicating the level of these receptors in vivo (42). Therefore, 9D9 antibody protein was purified from mouse ascites fluid, labeled with ${ }^{125} \mathrm{I}$, and intravenously administered to rabbits. Its removal from plasma was determined as described previously (43). 
LDL clearance. Normal human LDL $(d=1.019-1.063 \mathrm{~g} / \mathrm{ml})$ were isolated, labeled with ${ }^{125} \mathrm{I}$, and intravenously administered to rabbits. Their removal from plasma was determined as described previously (41). The binding affinity of apo E-free human LDL for rabbit fibroblast LDL receptors is about half of that found for the corresponding receptors on human fibroblasts (10). The labeled human LDL would be expected to have essentially the same composition in both transgenic and control rabbits during the relatively short time of the experiment, thereby minimizing the effect of lipid composition on clearance $(44,45)$ and serving as an independent indicator of the ability of rabbit receptors in vivo to clear LDL.

Lipoprotein lipolysis. The susceptibility of VLDL $(d<1.006$ $\mathrm{g} / \mathrm{ml})$ and large LDL $(d=1.02-1.04 \mathrm{~g} / \mathrm{ml})$ to lipolysis was determined by incubating $30 \mu \mathrm{g}$ of lipoprotein triglyceride for $30 \mathrm{~min}$ at $37^{\circ} \mathrm{C}$ with $10 \mu \mathrm{l}$ of VLDL-depleted postheparin rabbit plasma and then quantitating the released fatty acids (46) by a colorimetric assay (Wako Chemicals, Richmond, VA). The postheparin plasma had been collected from normal control rabbits $10 \mathrm{~min}$ after the intravenous administration of $50 \mathrm{U}$ of heparin per $\mathrm{kg}$ body weight. The lipolysis assay was performed in the presence of $1.2 \mathrm{M} \mathrm{NaCl}$ to measure HL activity and in the absence of salt to measure total lipase activity; the difference was taken as a measure of lipoprotein lipase (LPL) activity (47).

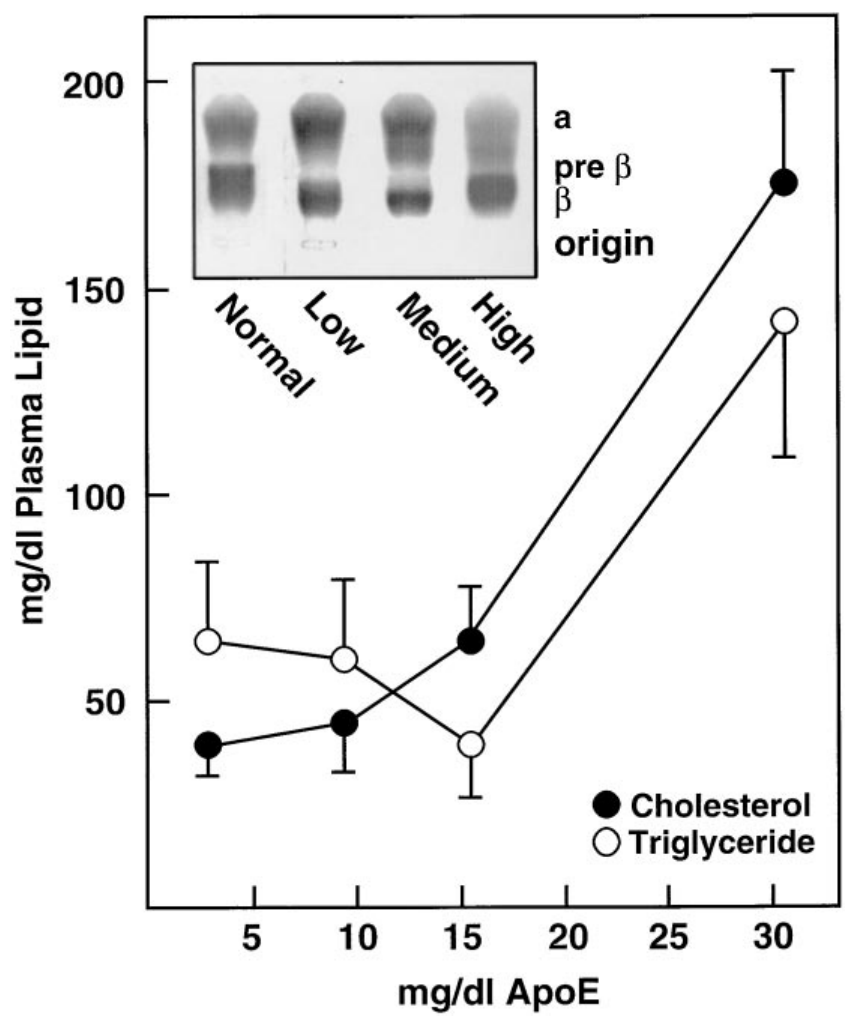

Figure 1. Effects of transgene expression on plasma lipid levels in apo E transgenic rabbits. Total triglyceride and total cholesterol levels were determined in whole plasma from normal rabbits and from the F1 hemizygous progeny of transgenic rabbits having additional production of human apo $\mathrm{E}$ in lines $\mathrm{A}$ (low expresser) and $\mathrm{C}$ (medium expresser), and from the $\mathrm{F} 2$ homozygous progeny of line $\mathrm{C}$ (high expresser) as described in the text. The horizontal axis gives the sum of endogenous rabbit apo $\mathrm{E}$ and transgenic human apo E. (Inset) Whole plasma from representative control and transgenic rabbits that has been resolved by agarose gel electrophoresis and stained for neutral lipids with Fat Red 7B. The electrophoretic mobilities of lipoprotein classes are indicated. Data are mean $\pm \operatorname{SD}(n=6-11$ animals/ group).

\section{Results}

Expression of human apo E3 in the transgenic rabbits. Three independent transgenic rabbit lines were established that expressed human apo E3 in their plasma at $\sim 6$ (line A), $\sim 11$ (line B), and $\sim 13 \mathrm{mg} / \mathrm{dl}$ (line C) in F1 hemizygotes. Western blot analysis showed that human apo E produced by the transgenic rabbits had a $M_{\mathrm{r}} \sim 35,000$, the same as that found in human plasma (data not shown). These transgenic rabbits developed normally and had normal breeding efficiency. Because the effects of transgene expression on lipoprotein metabolism were indistinguishable between lines $\mathrm{B}$ and $\mathrm{C}$ (data not shown), line $\mathrm{C}$ was used for most subsequent studies. F2 homozygotes were established for line $\mathrm{C}$ to provide a highexpresser line ( $\sim 26 \mathrm{mg} / \mathrm{dl}$ of human apo $\mathrm{E})$.

Plasma lipid levels. The effects of different levels of apo E production on total plasma lipids in male rabbits from each line are shown in Fig. 1. In low $(6 \mathrm{mg} / \mathrm{dl})$ and medium $(13 \mathrm{mg} / \mathrm{dl})$ expressers, triglycerides decreased progressively, whereas cholesterol increased in parallel with the level of apo E expression. These changes were associated with a reduction in pre$\beta$-migrating VLDL and an increase in $\beta$-migrating particles (Fig. 1, inset). At the highest levels of apo E expression, however, triglycerides increased along with cholesterol, and $\beta$-migrating particles accounted for most of the circulating lipoproteins.

The maximum reduction in triglyceride levels occurred in the intermediate expressers (13 mg/dl human apo E), an effect that is consistent with the role of apo $\mathrm{E}$ in remnant clearance. Our subsequent studies focused on these intermediate-expresser transgenic animals to determine how the decrease in VLDL and triglycerides might be linked to an increase in plasma cholesterol. Male and female intermediate expressers had 35 and $19 \%$ lower total plasma triglycerides, respectively, than nontransgenic littermates (Table I). In contrast, total plasma cholesterol was increased by $74 \%$ in transgenic males and $38 \%$ in transgenic females. In both sexes, HDL cholesterol levels were elevated, accounting for about one-fourth of the total increase in plasma cholesterol. Because the effect of apo E expression was somewhat greater in males, they were examined extensively; F1 animals from line C (intermediate expresser) were

Table I. Plasma Lipid Levels in Transgenic and Nontransgenic Rabbits

\begin{tabular}{lccc}
\hline \multicolumn{1}{c}{ Rabbits } & $\begin{array}{c}\text { Total } \\
\text { triglyceride }\end{array}$ & $\begin{array}{c}\text { Total } \\
\text { cholesterol }\end{array}$ & $\begin{array}{c}\text { HDL } \\
\text { cholesterol }\end{array}$ \\
\hline & & $m g / d l$ & \\
Males & & & \\
$\quad$ Transgenic $(n=11)$ & $43 \pm 11^{*}$ & $66 \pm 15^{*}$ & $36 \pm 12$ \\
$\quad$ Nontransgenic $(n=24)$ & $66 \pm 20$ & $38 \pm 12$ & $28 \pm 9$ \\
Females & & & \\
$\quad$ Transgenic $(n=22)$ & $50 \pm 17^{*}$ & $62 \pm 17^{*}$ & $37 \pm 7$ \\
$\quad$ Nontransgenic $(n=32)$ & $62 \pm 19$ & $45 \pm 10$ & $32 \pm 8$ \\
& & & \\
\hline
\end{tabular}

Rabbits, 4-6 mo old at the time of analysis, had been maintained on a standard high-fiber, low-fat diet, and then fasted for $16 \mathrm{~h}$ before analysis. Transgenic animals expressing $13 \mathrm{mg} / \mathrm{dl}$ human apo $\mathrm{E}$ (intermediate expressers) were used in this study. Values are mean \pm SD. Statistical significance was determined by paired two-tailed $t$ test. ${ }^{*} P<0.01$ versus nontransgenic rabbits. 

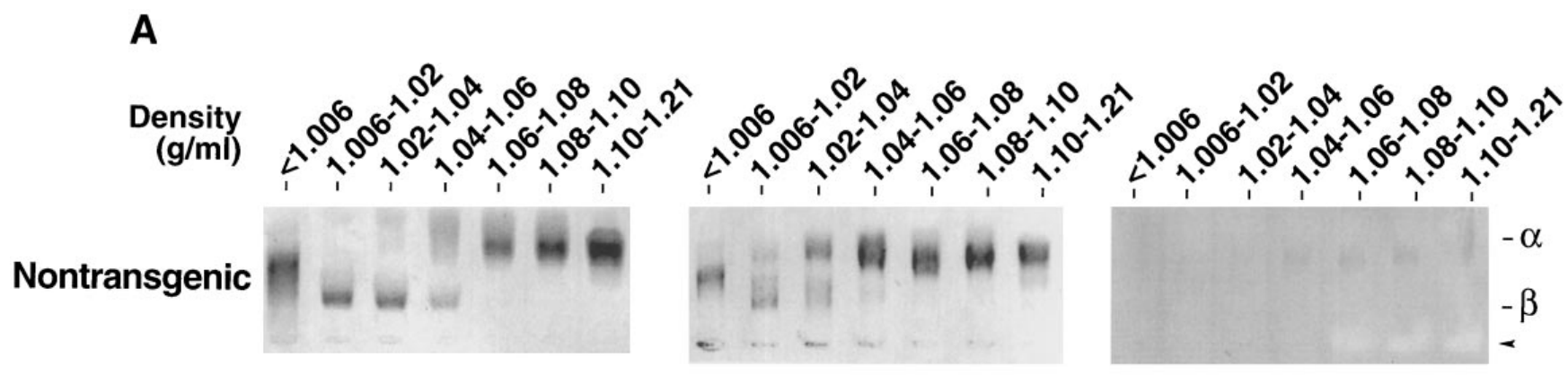

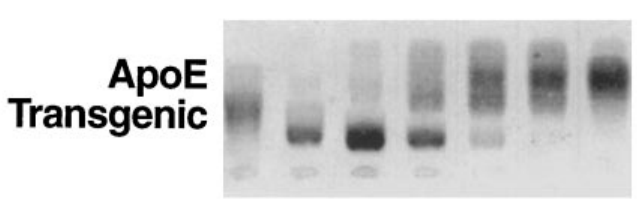

Fat Red 7B

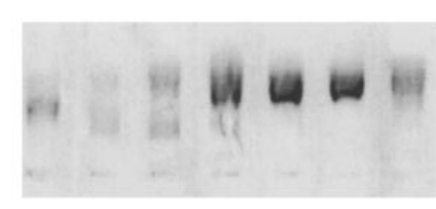

Anti-Rabbit ApoE

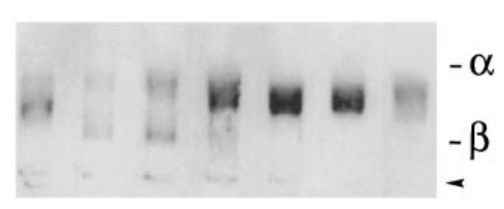

Anti-Human ApoE

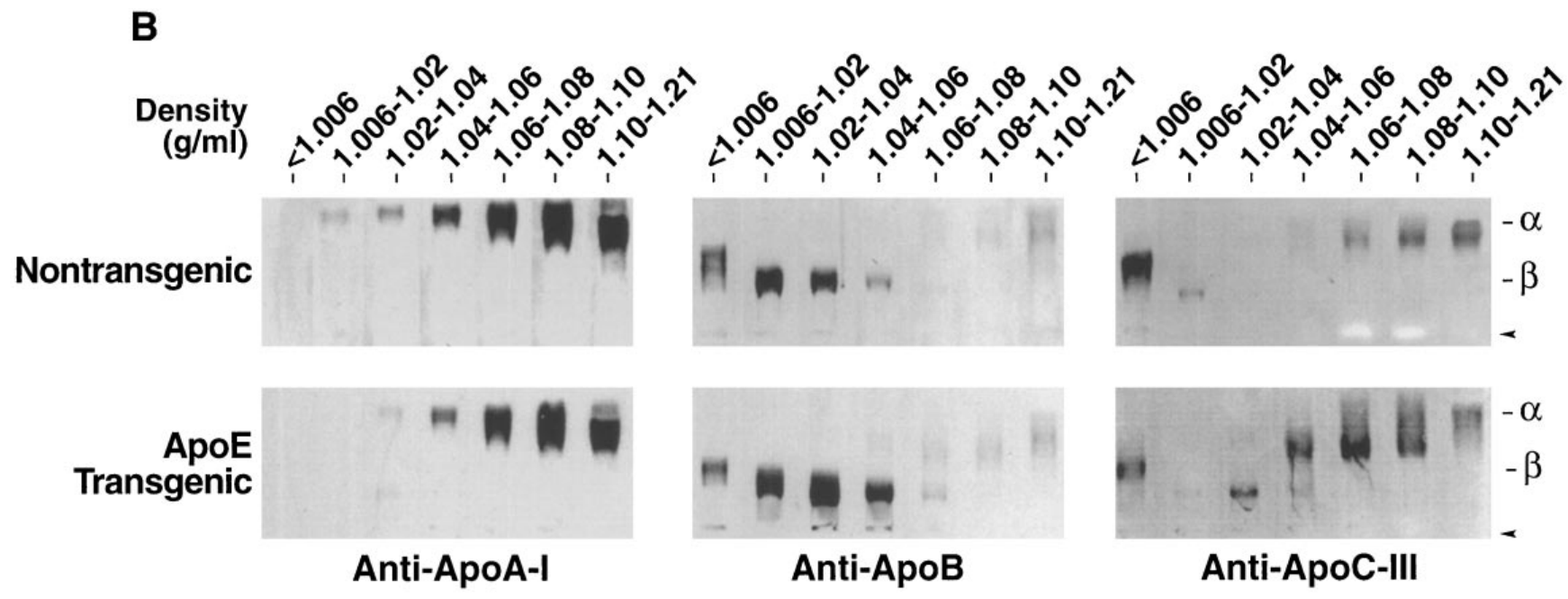

Figure 2. Effect of human apo E expression on rabbit lipoproteins. Plasma lipoproteins from fasting nontransgenic $(A)$ and transgenic male rabbits $(B)$ were separated by sequential density ultracentrifugation and resolved by electrophoresis in a $1 \%$ agarose gel. Lipoproteins were stained with Fat Red 7B $(A)$, and apolipoproteins were detected by immunoblotting with specific antibodies to human apo $\mathrm{E}(A)$ or rabbit proteins $(A$ and $B)$. The arrowhead denotes the origin; $\alpha$ and $\beta$ indicate electrophoretic mobility. Results from a representative animal in each group $(n=6)$ are shown.

used because they showed major but opposite effects on both triglyceride and cholesterol levels at a relatively modest increase in apo E levels.

Analysis of lipoproteins. Plasma lipoproteins from F1 transgenic rabbits (line $\mathrm{C}$ ) were separated by sequential density gradient centrifugation, resolved further by $1 \%$ agarose gel electrophoresis, and stained with Fat Red 7B (Fig. 2). The major lipoprotein classes in each fraction were: $d<1.006 \mathrm{~g} / \mathrm{ml}$, pre$\beta$-migrating VLDL; $d=1.006-1.02 \mathrm{~g} / \mathrm{ml}$, IDL; $d=1.02-1.04$ $\mathrm{g} / \mathrm{ml}$, large LDL; $d=1.04-1.06 \mathrm{~g} / \mathrm{ml}, \beta$-migrating small LDL and $\alpha$-migrating $\mathrm{HDL}_{1} ; d=1.06-1.08$ and $d=1.08-1.10 \mathrm{~g} / \mathrm{ml}$, $\mathrm{HDL}_{1}$ and $\mathrm{HDL}_{2}$; and $d=1.10-1.21 \mathrm{~g} / \mathrm{ml}, \mathrm{HDL}_{3}$. This qualitative analysis consistently showed three prominent changes in the relative amounts of different lipoproteins. Transgenic rabbits had lower VLDL levels, higher LDL levels, and an accumulation of $\mathrm{HDL}_{1}$ compared to nontransgenic littermates.

Immunoblot analysis with specific antibodies showed that transgenic human apo $\mathrm{E}$ had the same distribution as endogenous rabbit apo E (Fig. $2 A$ ) and had no effect on the distribution or plasma concentration of rabbit apo E. The apo E was found predominantly in the slow-migrating $\mathrm{HDL}_{1}$ (abundant in the $d=1.04-1.10 \mathrm{~g} / \mathrm{ml}$ fractions), with lesser amounts in VLDL, IDL, and large LDL. As expected, almost no apo E was found in small LDL. Apo A-I was found in typical $\alpha$-migrating HDL (Fig. $2 B$ ), which had a faster electrophoretic mobility than the apo E-containing $\mathrm{HDL}_{1}$. Like apo E, apo C-III was more abundant on large apo E-rich $\mathrm{HDL}_{1}$ and on large LDL in transgenic rabbits than in controls. The distribution of apo B was shifted by transgene expression, being most abundant in the IDL and both LDL fractions of transgenic rabbits. Denaturing PAGE indicated that both apo B100 and apo B48 were present in $d<1.006, d=1.006-1.02$, and $d=1.02-1.04 \mathrm{~g} / \mathrm{ml}$ fractions at the same relative levels in both control and transgenic animals: there did not appear to be a selective loss or accumu- 

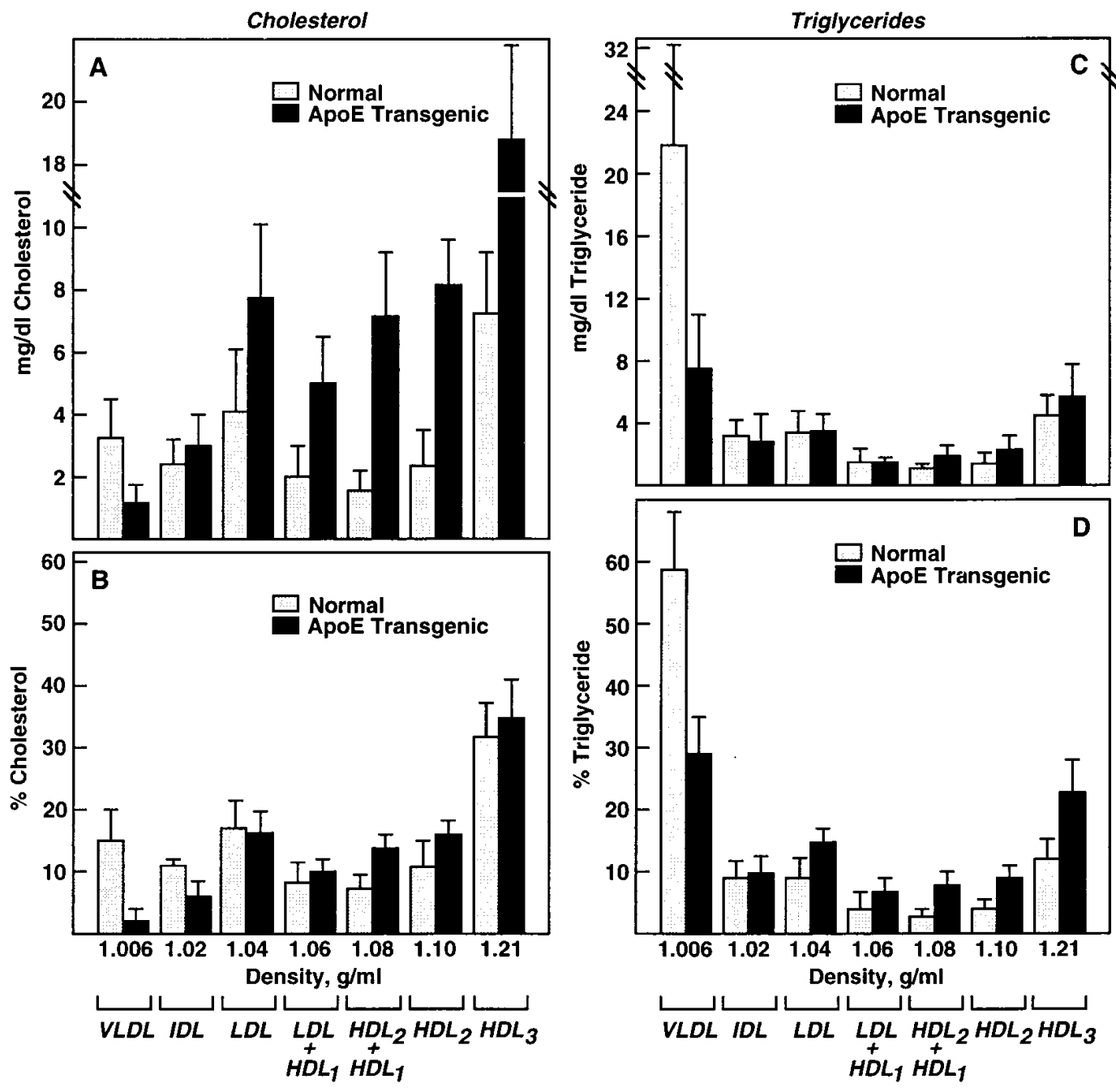

Figure 3. Lipid distribu-
tion in plasma lipopro-
teins at intermediate
levels of transgene ex-
pression. Density gradi-
ent fractions were col-
lected from medium-
expresser $(\sim 13 \mathrm{mg} / \mathrm{dl})$
apo E transgenic rabbits
as indicated in Fig. 2 , and
the cholesterol $(A)$ and
triglyceride contents $(C)$
were determined. To per-
mit a comparison be-
tween rabbits with differ-
ent total plasma lipid
levels, the relative distri-
butions of cholesterol and
triglyceride among the
various fractions were
plotted $(B$ and $D)$; the
combined recovery of
lipid for each animal
averaged $\sim 80 \%$ of total
plasma levels. Data are
mean $\pm S D(n=6$
animals/group).

lation of either form of apo B (data not shown).

The mean cholesterol and triglyceride content of the individual density fractions are shown in Fig. 3, $A$ and $C$, respectively, confirming the quantitative reduction in VLDL and the accumulation of cholesterol-rich LDL and HDL $\mathrm{L}_{1}$. These quantitative changes were reflected by the relative distribution of plasma cholesterol and triglyceride (Fig. 3, $B$ and $D$ ), which highlighted the striking reduction in VLDL levels in the apo $\mathrm{E}$ transgenic rabbits.

Analysis of the plasma lipoprotein distribution in the highexpressor $(26 \mathrm{mg} / \mathrm{dl}) \mathrm{F} 2$ transgenic rabbits showed that doubling the plasma apo E concentration resulted in an accumulation of even higher levels of large LDL (Fig. $4 A$ ). The IDL levels were also increased substantially: three-fourths of the cholesterol and more than half of the triglycerides were found in the $d=1.006-1.02$ and $d=1.02-1.04 \mathrm{~g} / \mathrm{ml}$ large LDL fractions (Fig. 4, $B$ and $D$ ). Thus, the elevated plasma triglyceride levels in the high expressers (Fig. 1) were due primarily to an accumulation of triglyceride-rich IDL and LDL (Fig. $4 C$ ). The density gradient fractions were analyzed further by agarose gel electrophoresis, lipid staining by Fat Red $7 \mathrm{~B}$, and immunoblotting (data not shown). The HDL in the $d=1.04-1.08 \mathrm{~g} / \mathrm{ml}$ lipoproteins were predominately apo E-rich $\mathrm{HDL}_{1}$, that accounted for at least half of the neutral lipid in those fractions.

Electron microscopy of lipoproteins. Lipoprotein sizes in the various density fractions were measured by negative-staining electron microscopy. The most striking differences between transgenic (F1 medium expressers) and nontransgenic lipoproteins were observed in the VLDL fraction (Fig. 5, $A$ and $B)$. The VLDL from both animals had a median diameter of $26 \mathrm{~nm}$; however, large particles (>36 nm diameter) were nearly absent from the transgenic rabbits, whereas they accounted for $\sim 20 \%$ of this fraction in normal rabbits (Fig. 5, C and $D$ ). One possible explanation for this finding is that overexpression of apo E redirected the synthesis of VLDL to smaller particles. However, it seems more likely, in view of the normal function of apo E (and by the results shown in Figs. 6 and 7), that large VLDL acquired extra apo E on their surfaces, thereby enhancing their receptor-mediated clearance.

VLDL from high-expresser apo E transgenic rabbits had a size distribution that was closely similar to medium-expresser VLDL, with a notable absence of large VLDL particles (data not shown). Considering that the lipid content in the $d<1.006$ $\mathrm{g} / \mathrm{ml}$ fraction was increased in high-expresser transgenic rabbits as compared to intermediate expressers, these findings indicated that there was a greater number of $d<1.006 \mathrm{~g} / \mathrm{ml}$ VLDL particles in the high expressers.

Analysis of the $d=1.04-1.06 \mathrm{~g} / \mathrm{ml}$ fraction from intermedi- 


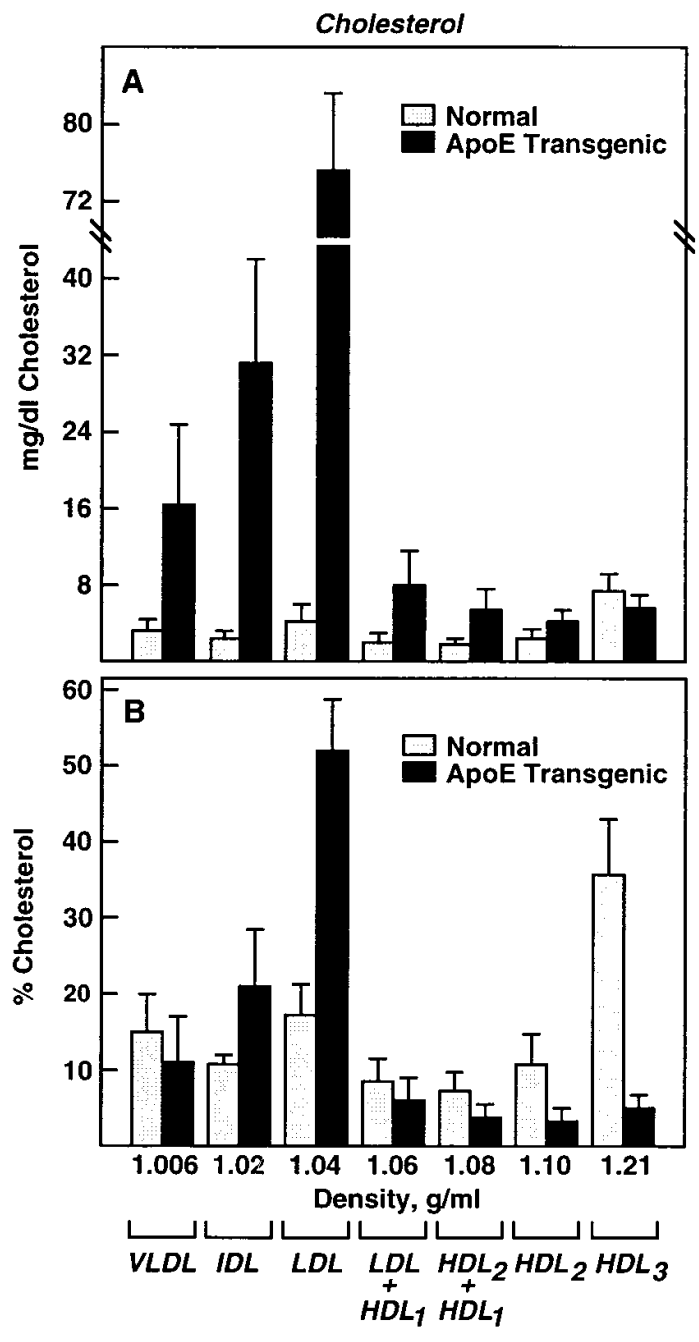

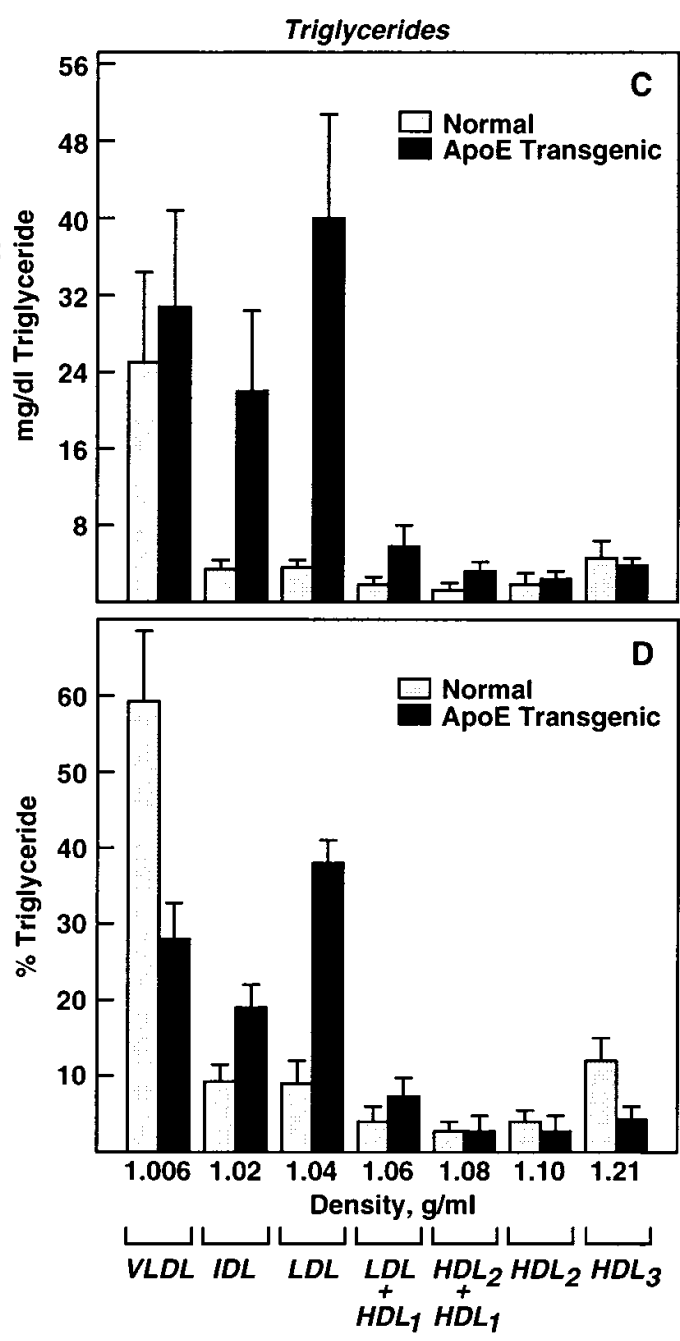

Figure 4. Lipid distribution in plasma lipoproteins at high levels of transgene expression. Density gradient fractions were collected from highexpresser $(\sim 27 \mathrm{mg} / \mathrm{dl})$ apo E transgenic rabbits and nontransgenic controls and analyzed as indicated in Fig. 3. Data are mean \pm SD. ate-expresser transgenic rabbits revealed an increase in the content of large lipoproteins (Fig. 5, $E$ and $F$ ). Particles with a diameter of $20 \mathrm{~nm}$ were more abundant in the transgenic rabbits than in nontransgenic controls, where smaller particles were more abundant (Fig. 5, $G$ and $H$ ). These findings are consistent with an accumulation of LDL in the apo E transgenic rabbits.

Receptor-binding assay. The ability of the rabbit lipoproteins to compete with human LDL for binding to the LDL receptor was measured with an in vitro assay using cultured human fibroblasts. The assays were performed on three separate preparations of lipoproteins from intermediate apo E expressers, and the same relative differences were observed each time. The VLDL from transgenic rabbits had an approximately fourfold greater binding affinity for the LDL receptor than nontransgenic VLDL (Fig. $6 A$ ). The $d=1.006-1.02 \mathrm{~g} / \mathrm{ml}$ transgenic IDL fraction had only 1.6 -fold greater binding affinity than control IDL for the LDL receptor (data not shown). The increased affinity of lipoproteins from the transgenic rabbits appears to result from a higher apo E content, as indicated by gel electrophoresis of the protein components of VLDL (Fig. 6 A).

In contrast, the $d=1.02-1.04 \mathrm{~g} / \mathrm{ml}$ lipoproteins, which con- sist primarily of large LDL together with low amounts of $\mathrm{HDL}_{1}$ (see Fig. $2 A$ ), from both transgenic and nontransgenic rabbits had similar receptor-binding activities (Fig. $6 \mathrm{~B}$ ). The same results (no difference in binding affinity) were observed when the $d=1.04-1.06 \mathrm{~g} / \mathrm{ml}$ lipoprotein fraction was examined with the fibroblast receptor-binding assay (data not shown). Although there was more apo $\mathrm{E}$ in this fraction in transgenic rabbits than in nontransgenic controls, most of the apo $\mathrm{E}$ was found on large $\mathrm{HDL}_{1}$ (Fig. $2 A$ ). In this regard, it has been shown previously in rats (48) and humans (49) that LDL and $\mathrm{HDL}_{1}$ have similar binding affinities for the LDL receptor.

The receptor-binding property of $\mathrm{HDL}_{1}$ from the apo $\mathrm{E}$ transgenic rabbit was investigated in a preliminary study. The $d=1.02-1.04 \mathrm{~g} / \mathrm{ml}$ and $d=1.04-1.10 \mathrm{~g} / \mathrm{ml}$ lipoproteins were isolated from intermediate-expresser transgenic animals; then homogeneous LDL (separated from $\mathrm{HDL}_{1}$ ) and apo E-rich $\mathrm{HDL}_{1}$ (separated from apo A-I-rich $\mathrm{HDL}_{2}$ ) were isolated by Pevikon gel electrophoresis. Their ability to compete with human LDL for binding to LDL receptors in the cultured human fibroblast assay was determined. The apo E-rich $\mathrm{HDL}_{1}$ were approximately twofold more effective than human LDL in competing with labeled human LDL in binding to LDL recep- 
A

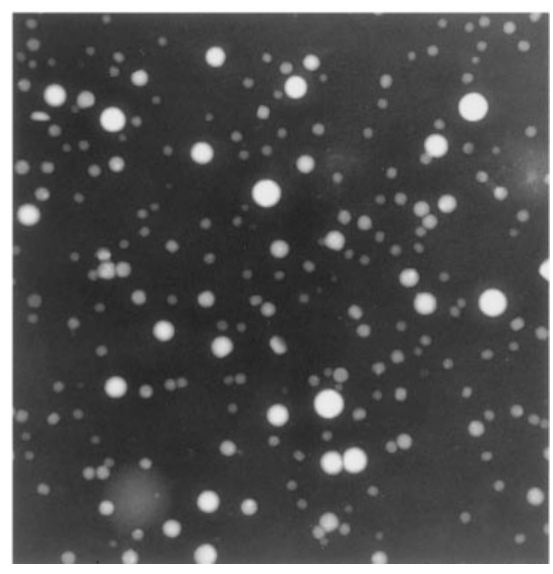

B

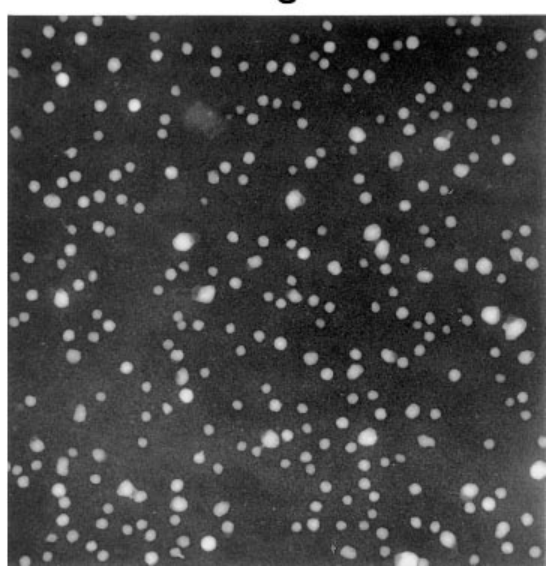

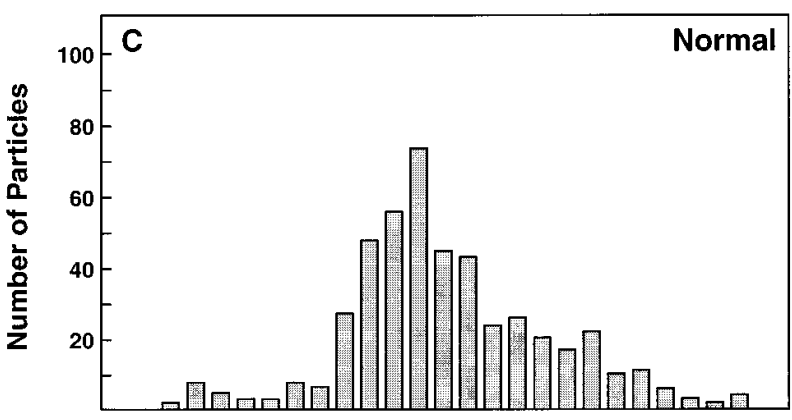

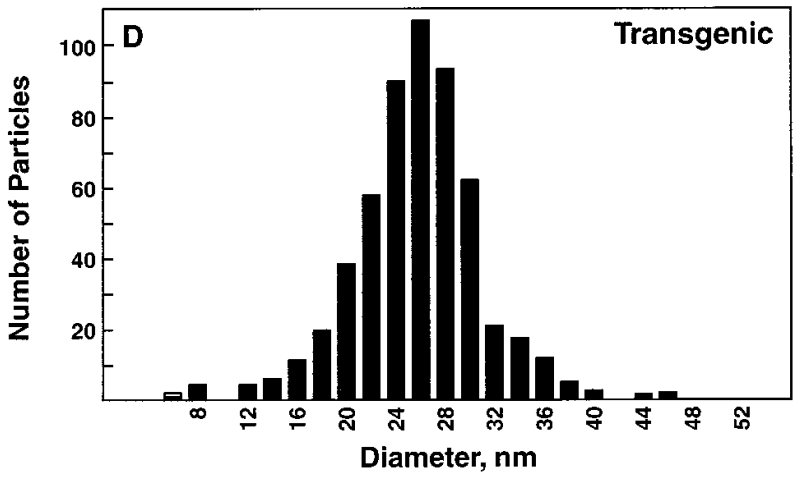

Figure 5. Size distribution of VLDL and LDL. The $d<1.006 \mathrm{~g} / \mathrm{ml}$ VLDL $(A-D)$ and $d=1.04$ $1.06 \mathrm{~g} / \mathrm{ml} \mathrm{LDL}(E-H)$ were isolated from normal $(n=3)$ and apo $\mathrm{E}$ transgenic $(n=3)$ rabbits by density gradient centrifugation and examined by negative-staining electron microscopy. Typical VLDL ( $A$ and $B$ ) and LDL ( $E$ and $F$ ) were observed at magnifications of $100(A$ and $B)$ and 200 $(E$ and $F)$. The diameters of $>500$ particles in each fraction were determined by digital image analysis (37), and the distribution of particle sizes is shown for VLDL ( $C$ and $D$ ) and LDL ( $G$ and $H$ ). Representative results from each group are shown. tors (data not shown). Thus, the accumulation of $\mathrm{HDL}_{1}$ in apo E transgenic rabbits was not likely due to an impairment in receptor-binding ability.

Chylomicron remnant clearance. Intravenously injected, radioactively labeled chylomicrons were cleared more rapidly from the plasma of F1 transgenic rabbits than from nontransgenic rabbits (Fig. $7 A$ ), and there was a corresponding increase in the uptake of radioactivity by the livers of transgenic animals (Fig. 7 B). These findings are consistent with the ability of apo $\mathrm{E}$ to mediate chylomicron remnant clearance from rabbit plasma via the LDL receptor, LRP, and HSPG pathways $(8,11,50-52)$. This increased rate of clearance is also consistent with the decreased content of plasma triglycerides and $d<1.006 \mathrm{~g} / \mathrm{ml}$ lipoproteins in these animals (Table I and Fig. 2).

Remnant uptake was increased only in the liver of the transgenic rabbits (Fig. $7 \mathrm{~B}$ ), consistent with previous findings that remnant uptake in bone marrow was not dependent on apo E (50). There was no redistribution of remnant uptake nor was there a decrease in uptake by any other tissue. The consequence of increased apo E for remnant uptake appeared to be limited to the liver. Taken together, the above experiments suggest that an increased apo E content on large remnant lipoproteins enhances their affinity for receptors, resulting in faster hepatic uptake. This mechanism could account for the decrease in plasma triglycerides.

LDL clearance. The $d=1.019-1.063 \mathrm{~g} / \mathrm{ml}$ LDL fraction from normal human plasma was isolated, labeled with ${ }^{125} \mathrm{I}$, and injected intravenously into rabbits, and the removal of these particles from plasma was determined. As shown in Fig. 8, LDL were cleared more slowly from the plasma of transgenic rabbits than from normal rabbits, consistent with the accumulation of LDL that was observed in the transgenic animals. The estimated $t_{1 / 2}$ for the clearance of labeled LDL is $6.0 \mathrm{~h}$ from control rabbits and $11.2 \mathrm{~h}$ from transgenic rabbits.

Clearance of $L D L$ receptor antibody. To determine if downregulation of receptors was responsible for the delay in LDL clearance, the number of cell surface LDL receptors in rabbits was assessed by the ability of these receptors to remove 9D9 monoclonal antibody from plasma. Although this measurement is indirect, previous studies demonstrated that the rate of clearance of 9D9 antibody is an effective measure of LDL receptor levels (42). Moreover, the receptor-mediated clearance of 9D9 antibody is not affected by plasma lipoprotein levels: it does not compete with LDL for binding to the LDL receptor (42). The labeled antibody was cleared at the same rate in transgenic and nontransgenic rabbits (Fig. 9), indicating equivalent levels of LDL receptors. Thus, it does not appear that downregulation of LDL receptors contributes to the delayed clearance of LDL from transgenic rabbit plasma.

Lipolysis of lipoproteins. In postheparin plasma, there was no significant difference in LPL activity between transgenic and control rabbits, even at high levels of apo E expression (data not shown). Therefore, we determined if there was a 

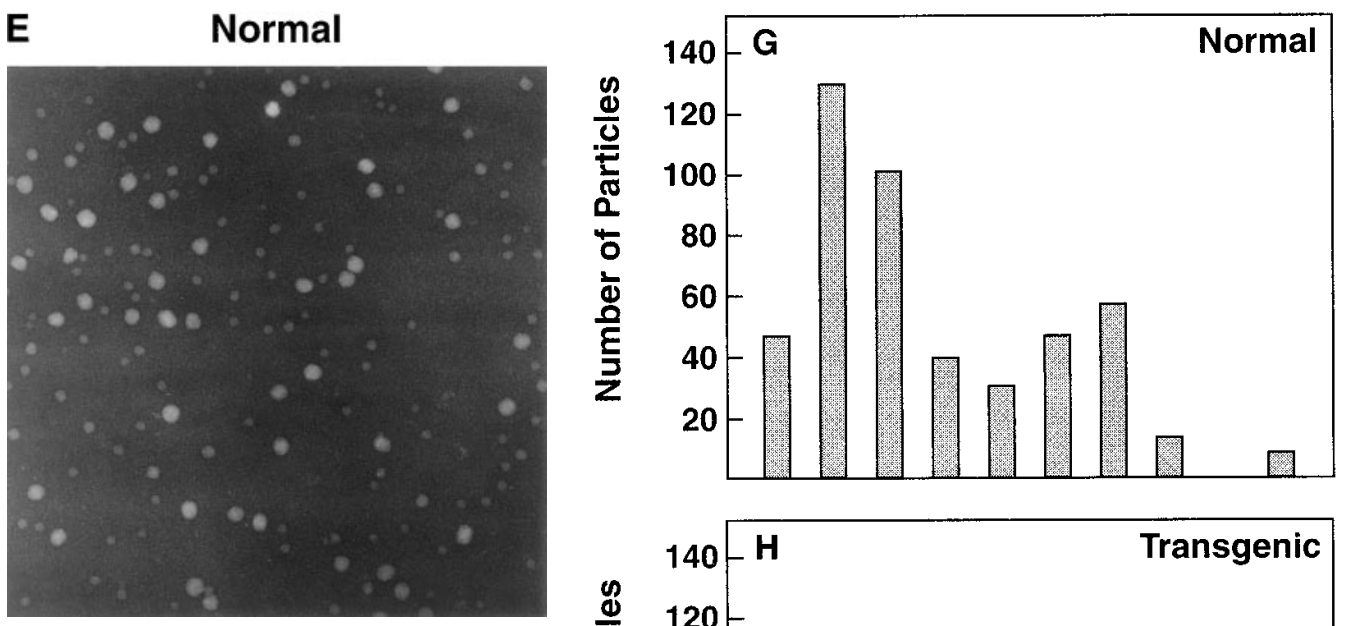

\section{F Transgenic}
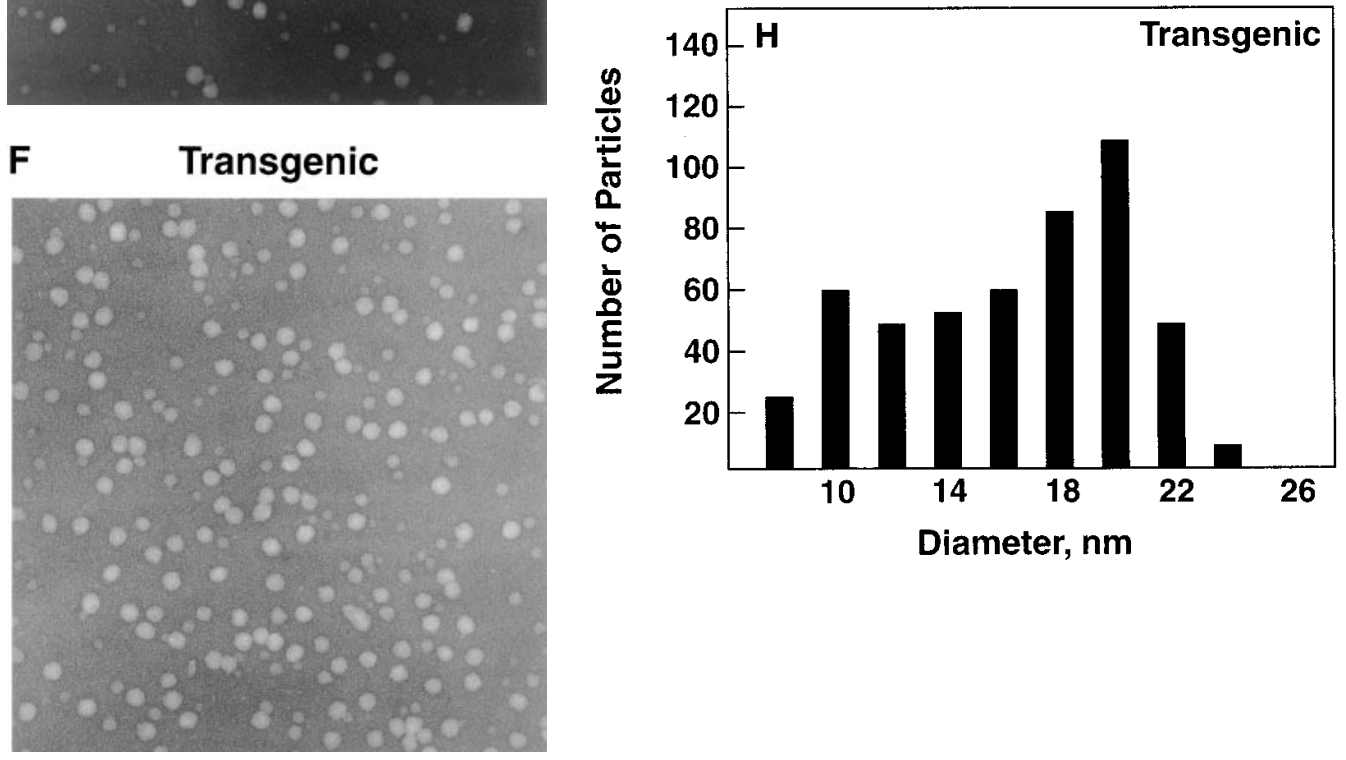

Figure 5 (Continued)

change in the susceptibility of postprandial $d<1.006 \mathrm{~g} / \mathrm{ml}$ VLDL and $d=1.02-1.04 \mathrm{~g} / \mathrm{ml} \mathrm{LDL}$ to lipolysis by LPL and HL. The VLDL from both intermediate- and high-expresser apo E transgenic rabbits were substantially less susceptible to hydrolysis by LPL than control VLDL (Fig. $10 A$ ). Lipolytic activity by HL was minimally reduced on transgenic VLDL (Fig. $10 \mathrm{~B}$ ). Thus, the finding that transgene expression resulted in reduced rates of hydrolysis by lipases argues against the possibility that an increased lipolysis of VLDL contributed to the accumulation of LDL or the reduction in VLDL content in plasma.

Compared to controls, transgenic LDL from both intermediate- and high-expresser animals showed a minimal reduction in susceptibility to LPL-mediated lipolysis (Fig. $10 \mathrm{C}$ ), but these particles were substantially more susceptible to hydrolysis by HL (Fig. $10 D$ ). Furthermore, endogenous HL activity in postheparin plasma was twofold greater in the transgenic rabbits than in controls (data not shown). Both findings are consistent with apo E's ability to activate HL (26). Thus, the accumulation of LDL in the transgenic rabbit was not due to an impairment in lipolysis by HL.

\section{Discussion}

Transgenic rabbits generated with the E3 isoform of human apo $\mathrm{E}$ had an unexpected elevation in the concentration of plasma cholesterol that was increased further at progressively higher expression levels of apo E (Fig. 1). The impact of apo E on plasma triglycerides, however, was variable: triglyceride levels decreased significantly in intermediate apo E expressers, but elevated substantially in high apo E expressers. These effects on plasma lipids were a direct reflection of changes in the levels of VLDL, LDL, and $\mathrm{HDL}_{1}$ caused by increased apo $\mathrm{E}$ expression. In medium $(\sim 13 \mathrm{mg} / \mathrm{dl})$ apo E expressers, our observations suggested that an increase in the content of apo $\mathrm{E}$ on large remnants gave them a competitive advantage for binding to the LDL receptor resulting in an accelerated clearance of VLDL and an accumulation in LDL and HDL . At high $(\sim 26 \mathrm{mg} / \mathrm{ml})$ levels of expression, excess apo E resulted in the accumulation of larger triglyceride-rich particles as well as LDL, suggesting that IDL metabolism was also impaired.

Our studies show that the rabbit is a sensitive model for examining the role of apo $\mathrm{E}$ in lipoprotein metabolism. The sensitivity of the rabbit to changes in transgenic apo E expression may be a consequence of the somewhat low levels of endogenous apo $\mathrm{E}(16,17)$ as well as the natural deficiency in HL $(21)$ characteristic of this animal species. In this regard, in vitro studies show that HL enhances the role of apo E in remnant lipoprotein and HDL clearance $(25,27)$, and that HL lipolytic activity is activated by apo $\mathrm{E}$. Therefore, increasing apo E levels up to $\sim 13 \mathrm{mg} / \mathrm{dl}$ resulted in striking changes in plasma lipids compared to nontransgenic controls, which facilitated the 

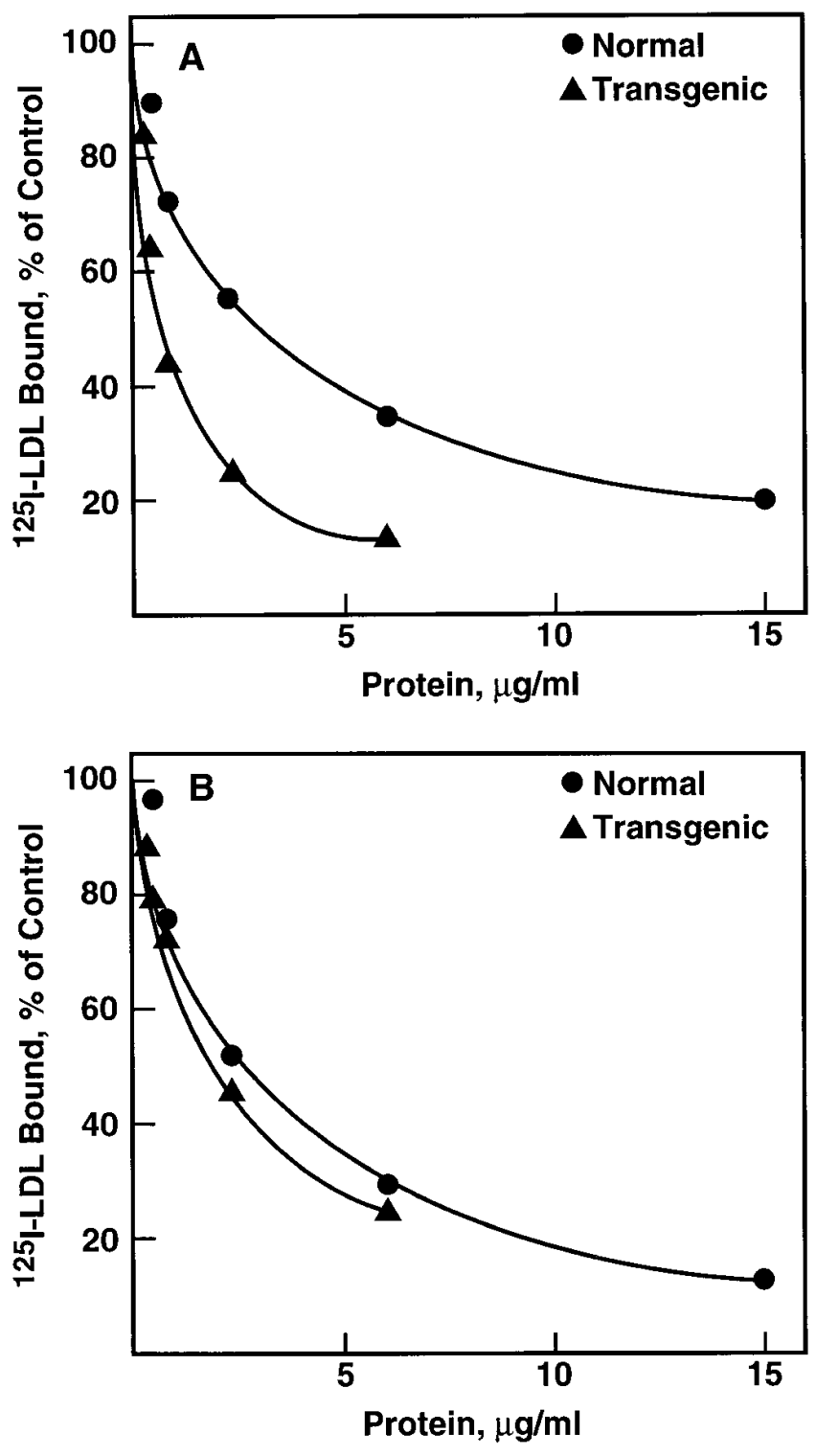

evaluation of the role of apo $\mathrm{E}$ in determining the distribution of lipoprotein subclasses.

The decrease in plasma triglycerides in the intermediate expressers was the result of a quantitative reduction in the content of VLDL triglycerides and cholesterol (Fig. 3, $A$ and $C$ ) and by the absence of large particles from the $d<1.006 \mathrm{~g} / \mathrm{ml}$ fraction (Fig. 5, $A-D$ ). Although decreased production might account for the reduction in circulating VLDL levels, our data indicated that faster clearance of remnants was the most likely explanation. This conclusion is consistent with previous studies showing that increased apo E content on lipoproteins correlates positively with enhanced receptor binding and cellular uptake, with apo E having a 20-fold greater affinity for the LDL receptor than apo $B$ (reviewed in references 10 and 11). Large VLDL from transgenic rabbits appeared to have a greater content of apo $\mathrm{E}$, and an in vitro assay showed that these particles had a higher affinity for the LDL receptor compared to controls (Fig. $6 \mathrm{~A}$ ). Intravenously administered chylomicrons were cleared more rapidly from transgenic rabbit plasma (Fig. $7 \mathrm{~A}$ ), suggesting that apo E redistributed quickly
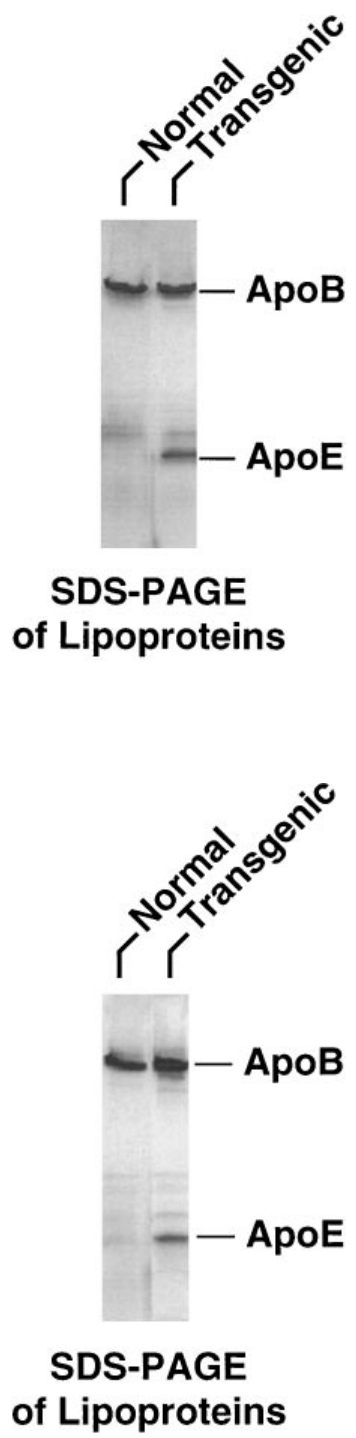

Figure 6. Binding of lipoproteins to the fibroblast LDL receptor. Human foreskin fibroblasts were grown to confluence in culture dishes, and the abilities of normal and transgenic $d<1.006 \mathrm{~g} / \mathrm{ml}$ lipoproteins $(A)$ or $d=1.02-1.04 \mathrm{~g} / \mathrm{ml}$ lipoproteins $(B)$ to compete with ${ }^{125} \mathrm{I}$ labeled human LDL for LDL receptor binding were assayed as described in Methods. Each panel shows a representative profile from three separate assays. Lipoproteins used for the receptor-binding assay were resolved by SDS-PAGE with $4-20 \%$ gels and stained with Coomassie blue. The apo $\mathrm{B}$ and apo E migration positions are indicated.

to the chylomicrons and directed their subsequent removal by receptors. In transgenic animals, nearly all of this enhanced uptake occurred in the liver, consistent with earlier investigations that demonstrated chylomicrons with excess apo $\mathrm{E}$ are cleared preferentially by the liver $(41,43,50)$. The major site for remnant removal is the space of Disse in the liver, where apo E directs binding to at least three different entities: the LDL receptor (53-55), the LRP (56), and HSPG $(8,52,57)$. The LDL receptor accounts for more than half of remnant uptake (53), and it has a preference for particles smaller than 50 $\mathrm{nm}$ in diameter (58).

We investigated the possibility that increased apo E levels might modulate the lipolysis of VLDL by LPL. In addition to its role in the hydrolysis of chylomicron and VLDL triglycerides (reviewed in references 59 and 60), LPL has been proposed as a ligand for lipoprotein remnant binding to the LRP (61). Dimeric LPL has been found on triglyceride-rich plasma lipoproteins (62), and LPL promotes the binding of apo B100 rich lipoproteins to cell surface HSPG independent of its enzyme activity (63), consistent with a ligand function for LPL. 

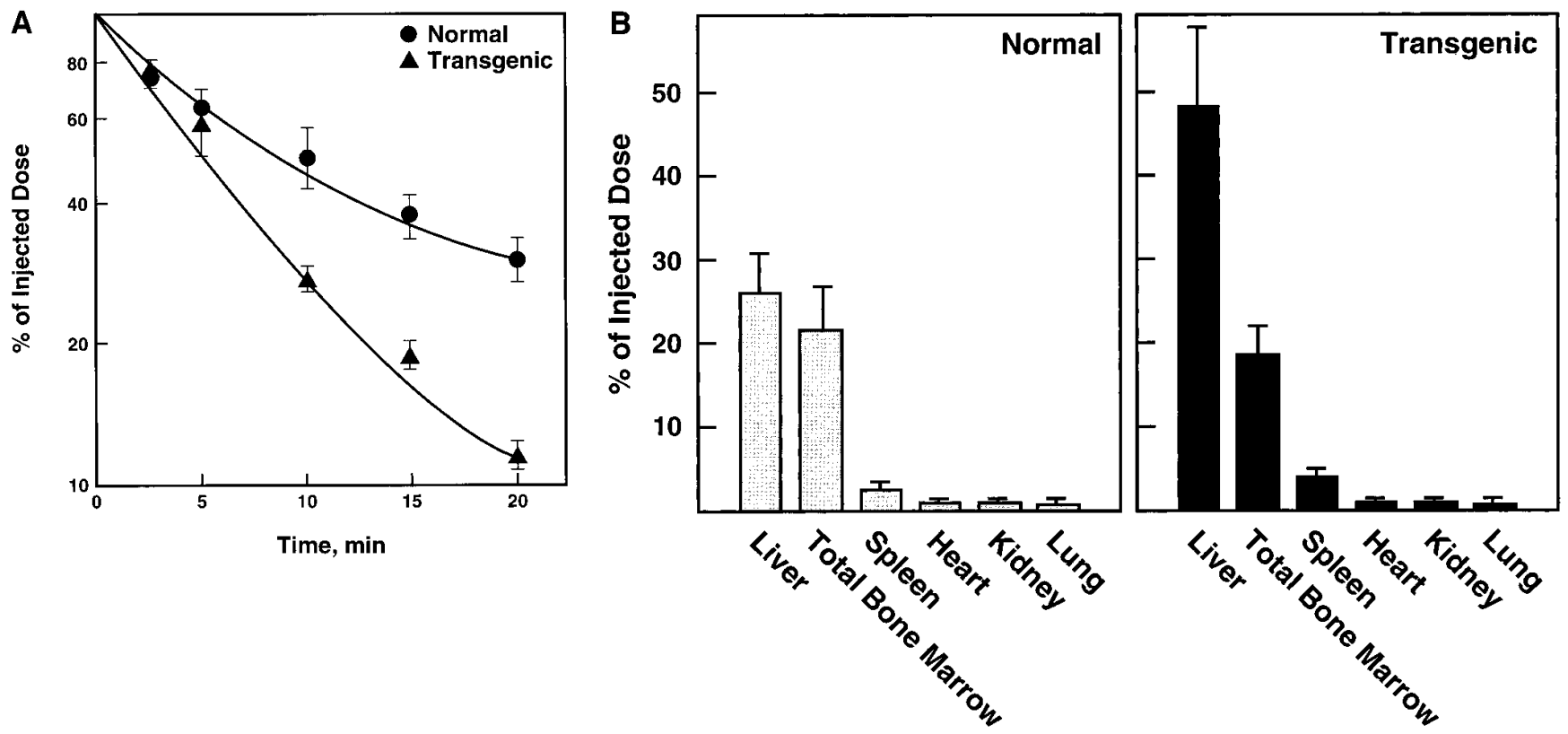

Figure 7. Chylomicron clearance in apo E transgenic and nontransgenic rabbits. The disappearance of radioactively labeled chylomicrons from plasma $(A)$ and the corresponding uptake by tissues after $20 \mathrm{~min}(B)$ were determined as indicated in Methods. Data are mean $\pm \mathrm{SD}(n=3)$.

The stimulation of VLDL binding to HSPG by LPL has been reported to be complementary to the enhancement of VLDL binding to HSPG by apo E (64). In contrast, apo E inhibits LPL-mediated lipolysis of chylomicron-like, triglyceride-rich lipid emulsions (65). These two different functional interactions of LPL and apo E are consistent with both the reduced VLDL content (Fig. 3) and the reduced susceptibility of post-

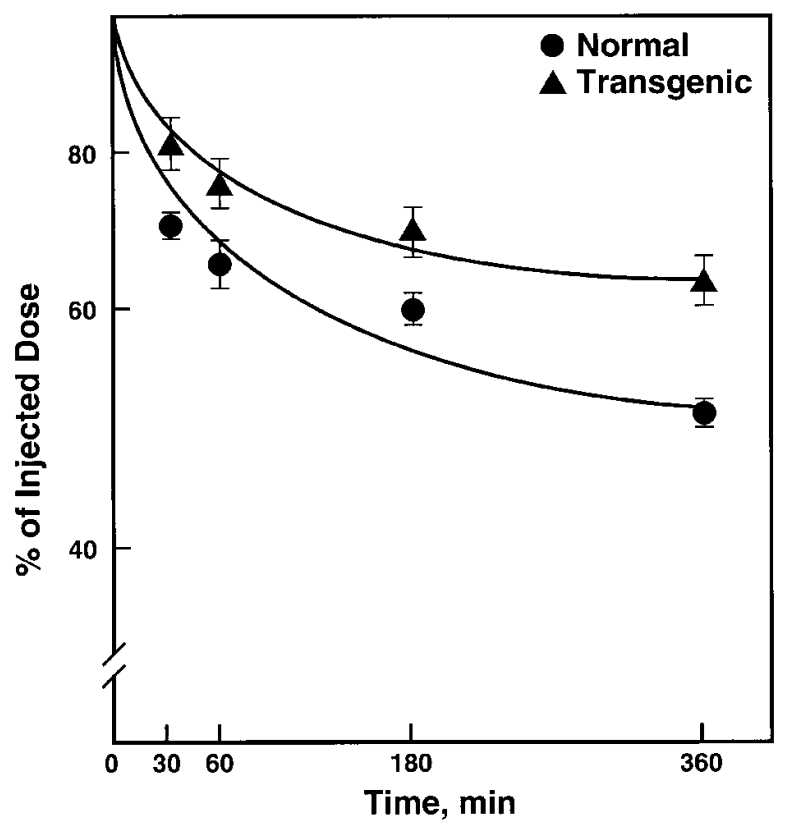

Figure 8. LDL clearance in apo E transgenic and nontransgenic rabbits. The disappearance of radioactively labeled human LDL from plasma was determined as described in Methods. Data are mean \pm SD $(n=3)$. prandial transgenic VLDL to hydrolysis by LPL (Fig. 10) in medium-expresser rabbits. Higher levels of apo E expression did not result in a greater inhibition of LPL catalytic activity (Fig. 10), suggesting that the inhibitory effect of apo E on LPL lipolysis may have been maximized at a moderate apo E level. However, a high excess of apo E might impair the ligand function of LPL, leading to an accumulation of triglyceride-rich

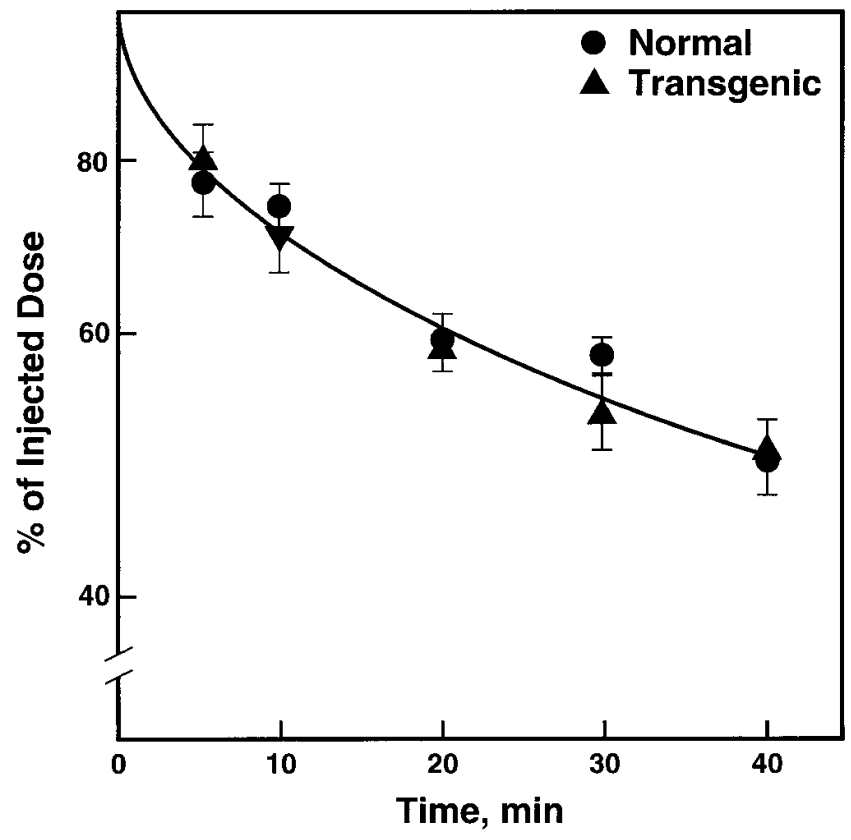

Figure 9. Clearance of LDL lipoprotein receptor antibody from the plasma of apo $\mathrm{E}$ transgenic and nontransgenic rabbits. The disappearance of radioactively labeled 9D9 monoclonal antibody from plasma was determined as described in Methods. Data are mean $\pm \operatorname{SD}(n=3)$. 
$V L D L$

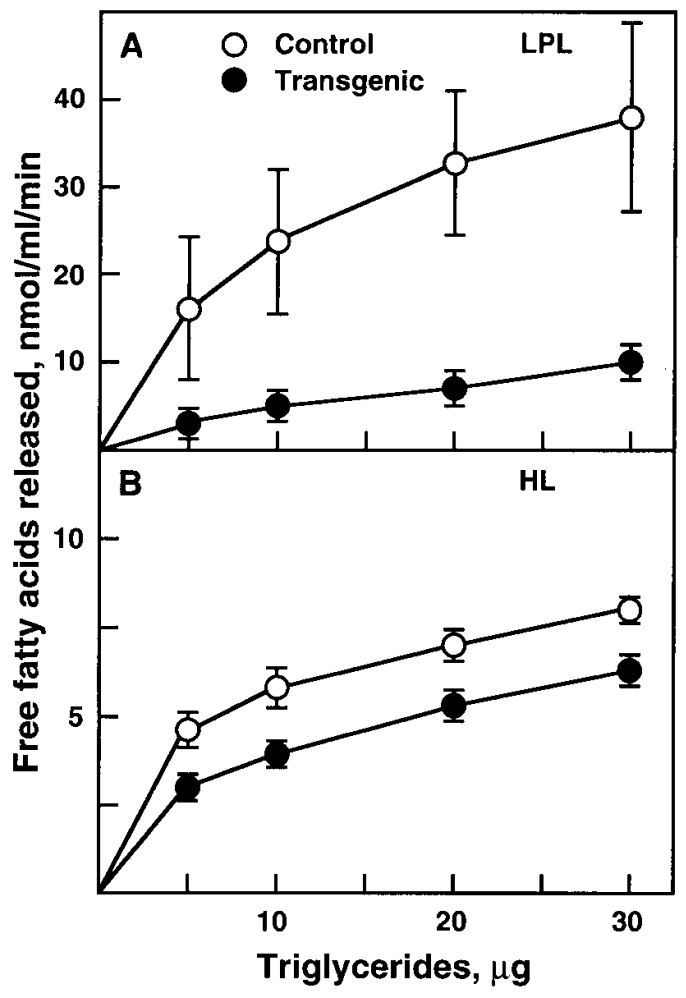

Large $L D L$

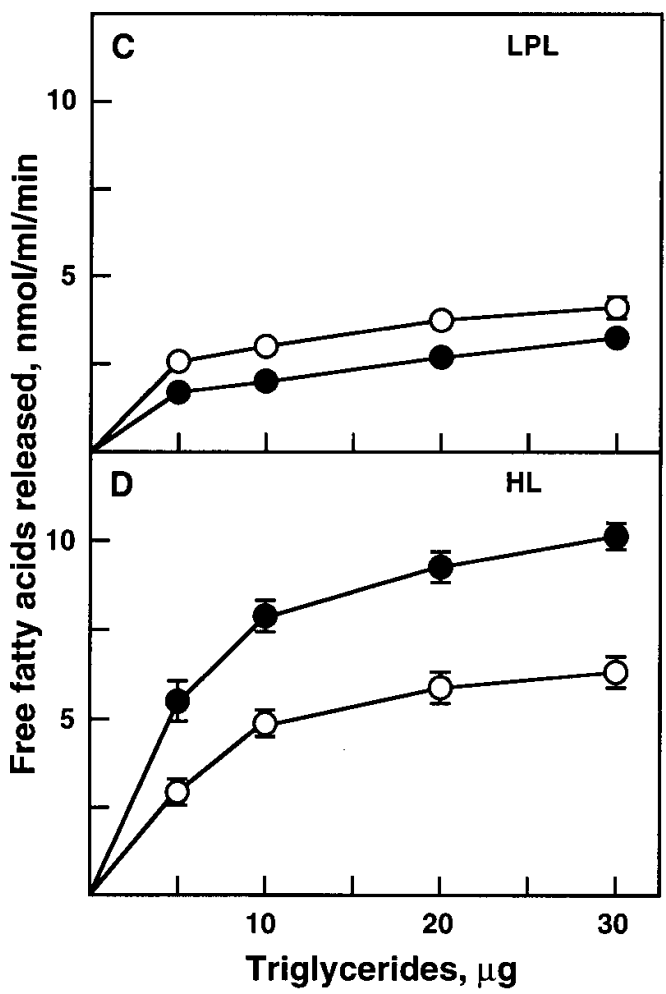

Figure 10. Lipolysis of VLDL and LDL. The $d<$ $1.006 \mathrm{~g} / \mathrm{ml}$ VLDL ( $A$ and $B)$ and $d=1.02-1.04 \mathrm{~g} / \mathrm{ml}$ LDL $(C$ and $D)$ were isolated from normal $(n=4)$ and apo E transgenic $(n=5)$ rabbits ( 3 medium and 2 high expressers) by density gradient centrifugation. Susceptibility to hydrolysis by LPL $(A$ and $C)$ and HL ( $B$ and $D$ ) was determined by measuring the release of free fatty acids as a function of an increasing concentration of the triglycerides in each fraction. Data are mean \pm SD. There was no significant difference in lipase susceptibility of lipoproteins from mediumand high-expresser apo E transgenic rabbits.
IDL and small VLDL in addition to LDL. This possibility remains to be tested in future studies of the high-expresser transgenic rabbits.

Surprisingly, plasma cholesterol levels were elevated in the apo $E$ transgenic rabbits. This elevation was not due to an apo $\mathrm{E}$ with defective receptor-binding properties, but instead resulted from an accumulation of large and small LDL and increased levels of apo E-rich $\mathrm{HDL}_{1}$ (Figs. 2 and 3). The large LDL fraction from transgenic rabbits (including a minor amount of $\mathrm{HDL}_{1}$ ) did not have a reduced binding affinity for the LDL receptor (Fig. $6 B$ ), making it unlikely that they were functionally defective particles. Most of the cholesterol in the apo B-containing lipoproteins of the medium-expresser transgenic rabbit was found in the LDL (Fig. $2 \mathrm{~B}$ ), consistent with the possibility that they were removed more slowly than larger lipoproteins. This possibility was supported by the finding that the plasma clearance of intravenously injected apo E-deficient human LDL was slower in transgenic rabbits than in nontransgenic controls. More importantly, however, 9D9 antibody was removed from the plasma of both transgenic and nontransgenic rabbits at the same rate, indicating that transgene expression did not significantly alter LDL receptor levels. Thus, transgenic LDL did not accumulate because of a reduction in LDL receptor activity.

A mechanism that could account for the accumulation of LDL in the apo $\mathrm{E}$ transgenic rabbits is competition by apo E-rich chylomicron and VLDL remnants for binding to the LDL receptor. The greater apo $\mathrm{E}$ content of remnants increases their binding affinity for the LDL receptor; consequently, the competitive advantage of the larger apo E-rich remnants for the receptor could impair LDL clearance. Competition for receptor binding has been proposed as a potential mechanism for some hyperlipidemias (reviewed in reference 66). Recently, apo $\mathrm{E}$ has been shown to cause a competitive inhibition of the receptor-dependent LDL uptake by the mouse liver (67), a finding that is consistent with our observations in apo $\mathrm{E}$ transgenic rabbits.

This competition mechanism might contribute to the reduced serum cholesterol that is characteristic of many subjects with the $\epsilon 2 / \epsilon 2$ genotype that do not develop overt type III hypercholesterolemia (reviewed in reference 13). The apo E2 isoform is consistently associated with lower total cholesterol and lower LDL cholesterol levels. The E2 isoform has reduced receptor-binding affinity $(10,11)$, which would decrease the ability of VLDL to bind to the LDL receptor. Consequently, LDL would be more competitive for receptor binding, consistent with the low LDL cholesterol levels in $\epsilon 2 / \epsilon 2$ individuals.

The IDL and LDL in hypertriglyceridemic high-expresser apo E transgenic rabbits are triglyceride-rich, a property that may contribute to their accumulation in plasma as lipid composition can modulate receptor-binding activity $(45,68)$. This observation suggests that these particles may not be lipolyzed efficiently by LPL in vivo, although LDL from high expressers were susceptible to hydrolysis in the in vitro assay. In this regard, large VLDL and chylomicrons are preferred substrates for LPL in vivo $(59,60)$, and it is possible that in high-expresser rabbits, the excess apo E results in a decreased ability of IDL and large LDL to interact with or have sufficient access to LPL. It is noteworthy that triglyceride-rich LDL are characteristic of hypertriglyceridemic humans (Huang, Y., unpublished studies); thus, the transgenic rabbits may serve as an in vivo model to investigate the mechanisms involved.

Several mechanisms may contribute to the accumulation of $\mathrm{HDL}_{1}$ in apo E transgenic rabbit plasma, including competi- 
tion for receptor binding. Although the rabbit $\mathrm{HDL}_{1}$ possesses a large quantity of apo $\mathrm{E}$, this characteristic does not necessarily mean that the rabbit $\mathrm{HDL}_{1}$ displays a high affinity for the LDL receptor. In fact, rat $\mathrm{HDL}_{1}$, which contains an abundance of apo E, binds to the LDL receptor with the same affinity as that of apo B-containing LDL (49). Our results are consistent with the rabbit $\mathrm{HDL}_{1}$ not possessing high-affinity receptor binding. The $d=1.04-1.06 \mathrm{~g} / \mathrm{ml}$ fraction, which contains a mixture of LDL and $\mathrm{HDL}_{1}$, did not demonstrate high-affinity binding despite the presence of a significant amount of apo E. Furthermore, isolated and purified $\mathrm{HDL}_{1}$ from the transgenic rabbits possessed only a twofold enhancement in receptor binding, as compared to LDL. Thus, increased competition of apo E-rich chylomicrons and VLDL remnants for the LDL receptor could result in a decreased clearance of $\mathrm{HDL}_{1}$ as well as LDL.

The accumulation of apo E-rich, large $\mathrm{HDL}_{1}$ may also be the consequence of low levels of VLDL. Because VLDL typically serves as a major acceptor of cholesteryl esters via cholesteryl ester transfer protein in exchange for triglyceride (24), the lack of sufficient VLDL for cholesterol transfer may augment the accumulation of cholesteryl ester-rich $\mathrm{HDL}_{1}$ as well as LDL. Another possible mechanism for the accumulation of $\mathrm{HDL}_{1}$ comes from the recent finding that a high concentration of apo E decreased the HL-mediated uptake of HDL by cultured hepatoma cells (27), perhaps reflecting competition between apo E and HL for HSPG-binding sites at the cell surface.

The increased expression of apo $\mathrm{E}$ in transgenic rabbits could result in a greater proportion of apo E-containing HDL within the total HDL population in plasma. Previous studies showed that the assembly of large $\mathrm{HDL}_{1}$ from smaller HDL is dependent upon the availability of apo E (54). The excess apo $E$ in high expressers would be expected to enhance this mechanism, thereby reducing the quantity of small HDL relative to larger subclasses. Furthermore, the assembly of $\mathrm{HDL}_{1}$ in rabbit plasma would be facilitated by the relative deficiency in HL activity, which functions normally to convert large HDL to smaller subclasses (22) and to increase cellular uptake of HDL (27), activities that would be reduced in the rabbit. Therefore, an increase in apo E production would be expected to favor the accumulation of $\mathrm{HDL}_{1}$ in transgenic rabbits.

A final consideration is that for each VLDL particle removed from plasma, a corresponding LDL particle would not be produced. Therefore, the accumulation of LDL in this model indicates that the increased expression of apo E influences more than one process affecting plasma LDL levels. As discussed above, several different components mediate VLDL and LDL clearance, including HL, LPL, the apo E content on lipoprotein surfaces, the activity of at least two different receptors, and HSPG. Apo E modulates the action of each of these components. In addition, LDL levels would be affected by the production of apo B-containing lipoproteins by the liver, as well as by lipolysis by LPL and HL. Further analysis of VLDL production and catabolism requires a detailed kinetic analysis beyond the scope of this manuscript.

The elevated LDL cholesterol in the transgenic rabbits suggested that they might develop spontaneous atherosclerosis. Therefore, we examined three high-expresser apo E transgenic rabbits that had been maintained on a standard chow diet for two years. Their plasma cholesterol levels ranged from 86 to $211 \mathrm{mg} / \mathrm{dl}$ at the time of killing. Their aortas were excised, trimmed of adventitial fat, fixed in 3\% paraformaldehyde, and stained with Sudan IV to detect lipid-containing atherosclerotic lesions as described (69). Extensive atherosclerosis was observed over the aortic surface of each rabbit (Taylor, J.M., unpublished observations). Thus, the chow-fed apo E3 transgenic rabbit may prove valuable as a model of spontaneous atherosclerosis. Studies are currently underway to evaluate the aortas of intermediate-expresser transgenic rabbits to determine the effect of lower levels of plasma cholesterol on lesion formation.

The transgenic rabbit is an important alternative to the transgenic mouse in evaluating the functions of apolipoproteins because species differences in metabolism may significantly affect results and conclusions. For example, overexpression of apo $\mathrm{E}$ in transgenic mice decreases plasma cholesterol without causing significant accumulation of LDL (70), in contrast to our observations in apo E transgenic rabbits. These differences may be a consequence of the absence of cholesteryl ester transfer protein and high levels of HL in mouse plasma. However, mouse liver typically edits about two-thirds of apo B100 mRNA to the apo B48 form $(29,71,72)$, which is likely to yield chylomicron-like particles as the dominant apo B-containing product of the mouse liver. Rabbit liver (like human liver) does not have apo B mRNA-editing capability $(29,71)$ and produces only apo B100 VLDL. Therefore, effects on apo B100 lipoproteins would be expected to be detected more easily in the rabbit. Overexpression of apo $E$ in the rabbit and mouse may affect the metabolism of apo B-containing lipoproteins differently in each species.

The findings presented here confirm the central role of apo $E$ in plasma cholesterol metabolism and extend our understanding of its regulatory function in lipoprotein pathways. By virtue of apo E's high affinity for lipoprotein receptors, its level in plasma can profoundly influence the composition of all major classes of lipoproteins, both directly and indirectly, thereby affecting plasma cholesterol homeostasis. The content of apo E on large remnant lipoproteins results in a higher affinity for receptors, giving them a competitive advantage over LDL in their clearance from plasma. Our data suggest that apo E-mediated competition for cell surface lipoprotein receptors may be an important mechanism for determining the content of LDL in plasma.

\section{Acknowledgments}

We thank Jean Wang for help with lipoprotein analysis, Ricky Quan for help in maintaining and bleeding rabbits, Karen Macleod and Alison Brown for help with rabbit surgery, Dale Newland for negativestaining electron microscopy, Kay Arnold for help with the receptorbinding assay, Helén Dichek for help and advice on lipase assays, Karl H. Weisgraber for providing rabbit antibodies, Lynne Shinto for performing apo E quantitation in plasma, Jim McGuire for the lipid analysis, the UCSF animal care staff for special assistance with rabbit maintenance, John C.W. Carroll and Amy Corder for graphic arts, Gary Howard and Stephen Ordway for editorial assistance, and Angela Chen for help with manuscript preparation.

This work was funded in part by National Institutes of Health grant HL51588. J. Fan was a recipient of an American Heart Association (California affiliate) fellowship award.

\section{References}

1. Mahley, R.W. 1988. Apolipoprotein E: cholesterol transport protein with expanding role in cell biology. Science. 240:622-630. 
2. Rall, S.C., Jr., K.H. Weisgraber, and R.W. Mahley. 1982. Human apolipoprotein E. The complete amino acid sequence. J. Biol. Chem. 257:4171-4178.

3. Paik, Y.-K., D.J. Chang, C.A. Reardon, G.E. Davies, R.W. Mahley, and J.M. Taylor. 1985. Nucleotide sequence and structure of the human apolipoprotein E gene. Proc. Natl. Acad. Sci. USA. 82:3445-3449.

4. Das, H.K., J. McPherson, G.A.P. Bruns, S.K. Karathanasis, and J.L. Breslow. 1985. Isolation, characterization, and mapping to chromosome 19 of the human apolipoprotein E gene. J. Biol. Chem. 260:6240-6247.

5. Kraft, H.G., H.J. Menzel, F. Hoppichler, W. Vogel, and G. Utermann. 1989. Changes of genetic apolipoprotein phenotypes caused by liver transplantation. Implications for apolipoprotein synthesis. J. Clin. Invest. 83:137-142.

6. Elshourbagy, N.A., W.S. Liao, R.W. Mahley, and J.M. Taylor. 1985 Apolipoprotein E mRNA is abundant in the brain and adrenals, as well as in the liver, and is present in other peripheral tissues of rats and marmosets. Proc. Natl. Acad. Sci. USA. 82:203-207.

7. Linton, M.F., R. Gish, S.T. Hubl, E. Bütler, C. Esquivel, W.I. Bry, J.K. Boyles, M.R. Wardell, and S.G. Young. 1991. Phenotypes of apolipoprotein B and apolipoprotein E after liver transplantation. J. Clin. Invest. 88:270-281.

8. Ji, Z.-S., S. Fazio, Y.-L. Lee, and R.W. Mahley. 1994. Secretion-capture role for apolipoprotein $\mathrm{E}$ in remnant lipoprotein metabolism involving cell surface heparan sulfate proteoglycans. J. Biol. Chem. 269:2764-2772.

9. Mahley, R.W., and S.C. Rall, Jr. 1995. Type III hyperlipoproteinemia (dysbetalipoproteinemia): the role of apolipoprotein $\mathrm{E}$ in normal and abnormal lipoprotein metabolism. In The Metabolic and Molecular Bases of Inherited Disease. 7th ed. C.R. Scriver, A.L. Beaudet, W.S. Sly, and D. Valle, editors. McGraw-Hill, New York. 1953-1980.

10. Mahley, R.W., and T.L. Innerarity. 1983. Lipoprotein receptors and cholesterol homeostasis. Biochim. Biophys. Acta. 737:197-222.

11. Mahley, R.W. 1996. Heparan sulfate proteoglycan/low density lipoprotein receptor-related protein pathway involved in type III hyperlipoproteinemia and Alzheimer's disease. Isr. J. Med. Sci. 32:414-429.

12. Dong, L.-M., and K.H. Weisgraber. 1996. Human apolipoprotein E4 domain interaction. Arginine 61 and glutamic acid 255 interact to direct the preference for very low density lipoproteins. J. Biol. Chem. 271:19053-19057.

13. Davignon, J., R.E. Gregg, and C.F. Sing. 1988. Apolipoprotein E polymorphism and atherosclerosis. Arteriosclerosis. 8:1-21.

14. Strittmatter, W.J., K.H. Weisgraber, D.Y. Huang, L.-M. Dong, G.S. Salvesen, M. Pericak-Vance, D. Schmechel, A.M. Saunders, D. Goldgaber, and A.D. Roses. 1993. Binding of human apolipoprotein $\mathrm{E}$ to synthetic amyloid $\beta$ peptide: isoform-specific effects and implications for late-onset Alzheimer disease. Proc. Natl. Acad. Sci. USA. 90:8098-8102.

15. Nathan, B.P., S. Bellosta, D.A. Sanan, K.H. Weisgraber, R.W. Mahley, and R.E. Pitas. 1994. Differential effects of apolipoproteins E3 and E4 on neuronal growth in vitro. Science. 264:850-852.

16. Havel, R.J., T. Kita, L. Kotite, J.P. Kane, R.L. Hamilton, J.L. Goldstein, and M.S. Brown. 1982. Concentration and composition of lipoproteins in blood plasma of the WHHL rabbit. An animal model of human familial hypercholesterolemia. Arteriosclerosis. 2:467-474.

17. Lusis, A.J., B.A. Taylor, D. Quon, S. Zollman, and R.C. LeBoeuf. 1987. Genetic factors controlling structure and expression of apolipoproteins B and E in mice. J. Biol. Chem. 262:7594-7604.

18. Mahley, R.W., K.H. Weisgraber, M.M. Hussain, B. Greenman, M. Fisher, T. Vogel, and M. Gorecki. 1989. Intravenous infusion of apolipoprotein $\mathrm{E}$ accelerates clearance of plasma lipoproteins in rabbits. J. Clin. Invest. 83: 2125-2130.

19. Yamada, N., H. Shimano, H. Mokuno, S. Ishibashi, T. Gotohda, M. Kawakami, Y. Watanabe, Y. Akanuma, T. Murase, and F. Takaku. 1989. Increased clearance of plasma cholesterol after injection of apolipoprotein E into Watanabe heritable hyperlipidemic rabbits. Proc. Natl. Acad. Sci. USA. 86:665669.

20. Overturf, M.L., and D.S. Loose-Mitchell. 1992. In vivo model systems: the choice of the experimental animal model for analysis of lipoproteins and atherosclerosis. Curr. Opin. Lipidol. 3:179-185.

21. Warren, R.J., D.L. Ebert, A. Mitchell, and P.J. Barter. 1991. Rabbit hepatic lipase cDNA sequence: low activity is associated with low messenger RNA levels. J. Lipid Res. 32:1333-1339.

22. Kinnunen, P.K.J. 1984. Hepatic endothelial lipase. Isolation, some characteristics, and physiological role. In Lipases. B. Borgström and H.L. Brockman, editors. Elsevier Science Publishers, Amsterdam. 307-328.

23. Sanan, D.A., J. Fan, A. Bensadoun, and J.M. Taylor. 1997. Hepatic lipase is abundant on both hepatocyte and endothelial cell surfaces in the liver. $J$. Lipid Res. 38:1002-1013.

24. Tall, A.R. 1986. Plasma lipid transfer proteins. J. Lipid Res. 27:361-367.

25. Ji, Z.-S., S.J. Lauer, S. Fazio, A. Bensadoun, J.M. Taylor, and R.W. Mahley. 1994. Enhanced binding and uptake of remnant lipoproteins by hepatic lipase-secreting hepatoma cells in culture. J. Biol. Chem. 269:13429-13436.

26. Thuren, T., R.W. Wilcox, P. Sisson, and M. Waite. 1991. Hepatic lipase hydrolysis of lipid monolayers. Regulation by apolipoproteins. J. Biol. Chem. 266:4853-4861

27. Ji, Z.-S., H.L. Dichek, R.D. Miranda, and R.W. Mahley. Heparan sulfate proteoglycans participate in hepatic lipase- and apolipoprotein E-mediated binding and uptake of plasma lipoproteins, including high density lipoproteins.
J. Biol. Chem. 272:31285-31292.

28. Tall, A.R. 1993. Plasma cholesteryl ester transfer protein. J. Lipid Res. 34:1255-1274

29. Yamanaka, S., M.E. Balestra, L.D. Ferrell, J. Fan, K.S. Arnold, S. Taylor, J.M. Taylor, and T.L. Innerarity. 1995. Apolipoprotein B mRNA-editing protein induces hepatocellular carcinoma and dysplasia in transgenic animals. Proc. Natl. Acad. Sci. USA. 92:8483-8487.

30. Poorman, J.A., R.A. Buck, S.A. Smith, M.L. Overturf, and D.S. LooseMitchell. 1993. Bile acid excretion and cholesterol $7 \alpha$-hydroxylase expression in hypercholesterolemia-resistant rabbits. J. Lipid Res. 34:1675-1685.

31. Simonet, W.S., N. Bucay, S.J. Lauer, and J.M. Taylor. 1993. A far-downstream hepatocyte-specific control region directs expression of the linked human apolipoprotein E and C-I genes in transgenic mice. J. Biol. Chem. 268: 8221-8229.

32. Fan, J., J. Wang, A. Bensadoun, S.J. Lauer, Q. Dang, R.W. Mahley, and J.M. Taylor. 1994. Overexpression of hepatic lipase in transgenic rabbits leads to a marked reduction of plasma high density lipoproteins and intermediate density lipoproteins. Proc. Natl. Acad. Sci. USA. 91:8724-8728.

33. Taylor, J.M., and J. Fan. 1997. Transgenic rabbit models for the study of atherosclerosis. Front. Biosci. 2:298-308.

34. Wahl, G.M., J.L. Meinkoth, and A.R. Kimmel. 1987. Northern and Southern blots. Methods Enzymol. 152:572-581.

35. Weisgraber, K.H. 1994. Apolipoprotein E: structure-function relationships. Adv. Protein Chem. 45:249-302.

36. Lee, B.-R., J.M. Miller, C.-Y. Yang, L. Ramdas, M. Yang, J.D. Morrisett, and M.P. Mims. 1991. Amino acid sequence of rabbit apolipoprotein E. $J$. Lipid Res. 32:165-171.

37. de Silva, H.V., S.J. Lauer, J. Wang, W.S. Simonet, K.H. Weisgraber, R.W. Mahley, and J.M. Taylor. 1994. Overexpression of human apolipoprotein C-III in transgenic mice results in an accumulation of apolipoprotein B48 remnants that is corrected by excess apolipoprotein E. J. Biol. Chem. 269:23242335

38. Innerarity, T.L., R.E. Pitas, and R.W. Mahley. 1979. Binding of arginine-rich (E) apoprotein after recombination with phospholipid vesicles to the low density lipoprotein receptors of fibroblasts. J. Biol. Chem. 254:4186-4190.

39. Arnold, K.S., T.L. Innerarity, R.E. Pitas, and R.W. Mahley. 1992. Lipoprotein-receptor interactions. In Lipoprotein Analysis. A Practical Approach C.A. Converse and E.R. Skinner, editors. Oxford University Press, Oxford. $145-168$.

40. Mahley, R.W., and K.H. Weisgraber. 1974. Canine lipoproteins and atherosclerosis. I. Isolation and characterization of plasma lipoproteins from control dogs. Circ. Res. 35:713-721.

41. Hussain, M.M., R.W. Mahley, J.K. Boyles, P.A. Lindquist, W.J. Brecht, and T.L. Innerarity. 1989. Chylomicron metabolism. Chylomicron uptake by bone marrow in different animal species. J. Biol. Chem. 264:17931-17938.

42. Huettinger, M., W.J. Schneider, Y.K. Ho, J.L. Goldstein, and M.S. Brown. 1984. Use of monoclonal anti-receptor antibodies to probe the expression of the low density lipoprotein receptor in tissues of normal and Watanabe Heritable Hyperlipidemic rabbits. J. Clin. Invest. 74:1017-1026.

43. Hussain, M.M., T.L. Innerarity, W.J. Brecht, and R.W. Mahley. 1995. Chylomicron metabolism in normal, cholesterol-fed, and Watanabe heritable hyperlipidemic rabbits. Saturation of the sequestration step of the remnant clearance pathway. J. Biol. Chem. 270:8578-8587.

44. Borensztajn, J., G.S. Getz, and T.J. Kotlar. 1988. Uptake of chylomicron remnants by the liver: further evidence for the modulating role of phospholipids. J. Lipid Res. 29:1087-1096.

45. McKeone, B.J., J.R. Patsch, and H.J. Pownall. 1993. Plasma triglycerides determine low density lipoprotein composition, physical properties, and cellspecific binding in cultured cells. J. Clin. Invest. 91:1926-1933.

46. Connelly, P.W., G.F. Maguire, C. Vezina, R.A. Hegele, and A. Kuksis. 1994. Kinetics of lipolysis of very low density lipoproteins by lipoprotein lipase. Importance of particle number and noncompetitive inhibition by particles with low triglyceride content. J. Biol. Chem. 269:20554-20560.

47. Iverius, P.-H., U. Lindahl, T. Egelrud, and T. Olivecrona. 1972. Effects of heparin on lipoprotein lipase from bovine milk. J. Biol. Chem. 247:66106616

48. Innerarity, T.L., R.E. Pitas, and R.W. Mahley. 1980. Receptor binding of cholesterol-induced high-density lipoproteins containing predominantly apoprotein $\mathrm{E}$ to cultured fibroblasts with mutations at the low-density lipoprotein receptor locus. Biochemistry. 19:4359-4365.

49. Hennessy, L.K., S.T. Kunitake, M. Jarvis, R.L. Hamilton, G. Endeman, A. Protter, and J.P. Kane. 1997. Isolation of subpopulations of high density lipoproteins: three particle species containing apo E and two species devoid of apo E that have affinity for heparin. J. Lipid Res. 38:1859-1868.

50. Hussain, M.M., R.W. Mahley, J.K. Boyles, M. Fainaru, W.J. Brecht, and P.A. Lindquist. 1989. Chylomicron-chylomicron remnant clearance by liver and bone marrow in rabbits. Factors that modify tissue-specific uptake. J. Biol. Chem. 264:9571-9582.

51. Hussain, M.M., F.R. Maxfield, J. Más-Oliva, I. Tabas, Z.-S. Ji, T.L. Innerarity, and R.W. Mahley. 1991. Clearance of chylomicron remnants by the low density lipoprotein receptor-related protein $/ \alpha_{2}$-macroglobulin receptor. $J$. Biol. Chem. 266:13936-13940. 
52. Ji, Z.-S., W.J. Brecht, R.D. Miranda, M.M. Hussain, T.L. Innerarity, and R.W. Mahley. 1993. Role of heparan sulfate proteoglycans in the binding and uptake of apolipoprotein E-enriched remnant lipoproteins by cultured cells. $J$. Biol. Chem. 268:10160-10167.

53. Choi, S.Y., L.G. Fong, M.J. Kirven, and A.D. Cooper. 1991. Use of an anti-low density lipoprotein receptor antibody to quantify the role of the LDL receptor in the removal of chylomicron remnants in the mouse in vivo. J. Clin. Invest. 88:1173-1181.

54. Koo, C., M.E. Wernette-Hammond, Z. Garcia, M.J. Malloy, R. Uauy, C. East, D.W. Bilheimer, R.W. Mahley, and T.L. Innerarity. 1988. Uptake of cholesterol-rich remnant lipoproteins by human monocyte-derived macrophages is mediated by low density lipoprotein receptors. J. Clin. Invest. 81: $1332-1340$.

55. Herz, J., S.-Q. Qiu, A. Oesterle, H.V. de Silva, S. Shafi, and R.J. Havel. 1995. Initial hepatic removal of chylomicron remnants is unaffected but endocytosis is delayed in mice lacking the low density lipoprotein receptor. Proc. Natl. Acad. Sci. USA. 92:4611-4615.

56. Kowal, R.C. J. Herz, J.L. Goldstein, V. Esser, and M.S. Brown 1989. Low density lipoprotein receptor-related protein mediates uptake of cholesteryl esters derived from apoprotein E-enriched lipoproteins. Proc. Natl. Acad. Sci. USA. 86:5810-5814.

57. Ji, Z.-S., D.A. Sanan, and R.W. Mahley. 1995. Intravenous heparinase inhibits remnant lipoprotein clearance from the plasma and uptake by the liver: in vivo role of heparan sulfate proteoglycans. J. Lipid Res. 36:583-592.

58. Rensen, P.C.N., N. Herijgers, M.H. Netscher, S.C.J. Meskers, M. van Eck, and T.J.C. van Berkel. 1997. Particle size determines the specificity of apolipoprotein E-containing triglyceride-rich emulsions for the LDL receptor versus hepatic remnant receptor in vivo. J. Lipid Res. 38:1070-1084.

59. Olivecrona, T., and G. Bengtsson-Olivecrona. 1990. Lipoprotein lipase and hepatic lipase. Curr. Opin. Lipidol. 1:222-230.

60. Eckel, R.H. 1989. Lipoprotein lipase. A multifunctional enzyme relevant to common metabolic diseases. N. Engl. J. Med. 320:1060-1068.

61. Beisiegel, U., W. Weber, and G. Bengtsson-Olivecrona. 1991. Lipoprotein lipase enhances the binding of chylomicrons to low density lipoprotein receptor-related protein. Proc. Natl. Acad. Sci. USA. 88:8342-8346.

62. Zambon, A., I. Schmidt, U. Beisiegel, and J.D. Brunzell. 1996. Dimeric lipoprotein lipase is bound to triglyceride-rich plasma lipoproteins. J. Lipid Res. 37:2394-2404
63. Williams, K.J., G.M. Fless, K.A. Petrie, M.L. Snyder, R.W. Brocia, and T.L. Swenson. 1992. Mechanisms by which lipoprotein lipase alters cellular metabolism of lipoprotein(a), low density lipoprotein, and nascent lipoproteins. Roles for low density lipoprotein receptors and heparan sulfate proteoglycans. J. Biol. Chem. 267:13284-13292.

64. van Barlingen, H.H.J.J., H de Jong, D.W. Erkelens, and T.W.A. de Bruin. 1996. Lipoprotein lipase-enhanced binding of human triglyceride-rich lipoproteins to heparan sulfate: modulation by apolipoprotein $\mathrm{E}$ and apolipoprotein C. J. Lipid Res. 37:754-763.

65. Rensen, P.C.N., and T.J.C. van Berkel. 1996. Apolipoprotein E effectively inhibits lipoprotein lipase-mediated lipolysis of chylomicron-like triglyceride-rich lipid emulsions in vitro and in vivo. J. Biol. Chem. 271:14791-14799.

66. Grundy, S.M. 1991. Multifactorial etiology of hypercholesterolemia. Implications for prevention of coronary heart disease. Arterioscler. Thromb. 11: 1619-1635.

67. Woollett, L.A., Y. Osono, J. Herz, and J.M. Dietschy. 1995. Apolipoprotein E competitively inhibits receptor-dependent low density lipoprotein uptake by the liver but has no effect on cholesterol absorption or synthesis in the mouse. Proc. Natl. Acad. Sci. USA. 92:12500-12504.

68. Mahley, R.W., and T.L. Innerarity. 1978. Properties of lipoproteins responsible for high affinity binding to cell surface receptors of fibroblasts and smooth muscle cells. Adv. Exp. Med. Biol. 109:99-127.

69. Huang, Y., S.W. Schwendner, S.C. Rall, Jr., D.A. Sanan, and R.W. Mahley. 1997. Apolipoprotein E2 transgenic rabbits: modulation of the type III hyperlipoproteinemic phenotype by estrogen and occurrence of spontaneous atherosclerosis. J. Biol. Chem. 272:22685-22694.

70. Shimano, H., N. Yamada, M. Katsuki, M. Shimada, T. Gotoda, K. Harada, T. Murase, C. Fukazawa, F. Takaku, and Y. Yazaki. 1992. Overexpression of apolipoprotein $\mathrm{E}$ in transgenic mice: marked reduction in plasma lipoproteins except high density lipoprotein and resistance against diet-induced hypercholesterolemia. Proc. Natl. Acad. Sci. USA. 89:1750-1754.

71. Greeve, J., I. Altkemper, J.-H. Dieterich, H. Greten, and E. Windler. 1993. Apolipoprotein B mRNA editing in 12 different mammalian species: hepatic expression is reflected in low concentrations of apo B-containing plasma lipoproteins. J. Lipid Res. 34:1367-1383.

72. Davidson, N.O. 1994. RNA editing of the apolipoprotein B gene. A mechanism to regulate the atherogenic potential of intestinal lipoproteins? Trends Cardiovasc. Med. 4:231-235. 